\title{
NOTITIE
}

\section{Stekende insecten Griendtsveen}

\author{
Maatregelfase 2015-2020
}

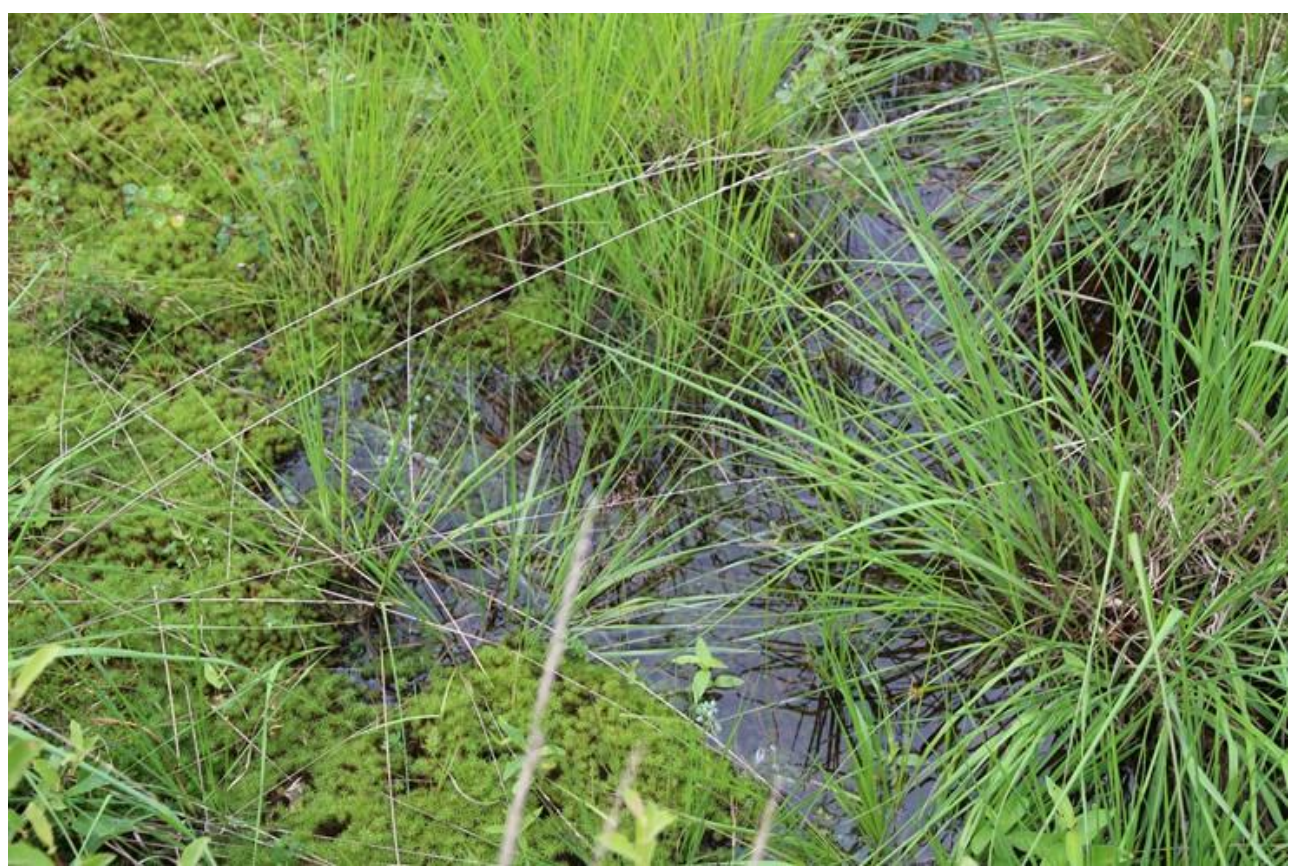

Piet Verdonschot 


\section{Auteurs}

Piet Verdonschot (correspondentie: piet.verdonschot@wur.nI)

\section{Opdrachtgever}

Staatsbosbeheer

\section{Projectgroep}

Eddy Boudewijns (Staatsbosbeheer)

\section{Wijze van citeren}

Verdonschot P.F.M. (2020). Stekende insecten Griendtsveen. Maatregelfase 2015-2020. Notitie Zoetwaterecosystemen, Wageningen Environmental Research, Wageningen UR, Wageningen. 42 pp.

\section{Trefwoorden}

Steekmuggen, knutten, hoogveenherstel, overlast, Mariapeel, Deurnsche Peel

\section{Beeldmateriaal}

Piet Verdonschot

DOI: https://doi.org/10.18174/548102

ISBN: 978-94-6395-847-9

Dit project is uitgevoerd in opdracht van Staatbosbeheer.

(C) 2021 Zoetwaterecosystemen, Wageningen Environmental Research

- Overname, verveelvoudiging of openbaarmaking van deze uitgave is toegestaan mits met duidelijke bronvermelding.

- Overname, verveelvoudiging of openbaarmaking is niet toegestaan voor commerciële doeleinden en/of geldelijk gewin.

- Overname, verveelvoudiging of openbaarmaking is niet toegestaan voor die gedeelten van deze uitgave waarvan duidelijk is dat de auteursrechten liggen bij derden en/of zijn voorbehouden.

Wageningen Environmental Research aanvaardt geen aansprakelijkheid voor eventuele schade voortvloeiend uit het gebruik van de resultaten van dit onderzoek of de toepassing van de adviezen. 


\section{Inhoud}

$\begin{array}{ll}\text { Inhoud } & 1\end{array}$

1 Inleiding 2

1.1 Aanleiding en vraag 2

1.2 Doel 2

2 Ontwikkelingen van stekende insecten van 2015 tot en met $2020 \quad 4$

2.1 Volwassen steekmuggen 4

2.2 Larven van de veenmoerassteekmug $(A$. cinereus $) \quad 8$

2.3 De ecologie van de veenmoerassteekmug (A. cinereus) 13

2.4 Knutten 13

2.5 De habitat van de belangrijkste knutten 17

$\begin{array}{ll}2.6 & \text { Weers-en gebiedsomstandigheden } \\ & 18\end{array}$

3 Overlast in het natuurgebied en in het dorp 25

3.1 Ontstaan van overlast 25

3.2 Ruimtelijke verdeling van de gewone veenmoerassteekmug (A. cinereus) 26

$\begin{array}{ll}3.3 & \text { Wanneer is sprake van overlast? } \\ & 29\end{array}$

4 Mogelijke beheer en interventiemaatregelen 30

$\begin{array}{lll}4.1 & \text { Inleiding } & 30\end{array}$

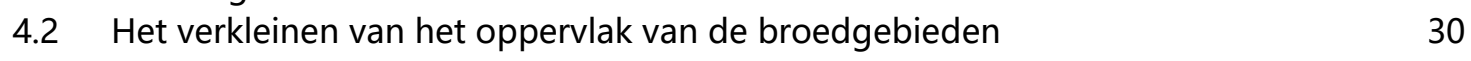

4.3 Veenmosontwikkeling en steekmug vermindering 31

4.4 Het beperken van de bereikbaarheid van het dorp voor steekmuggen 32

4.5 Samenvatting 32

$5 \quad$ Monitoring tijdens beheerfase 33

5.1 Inleiding 33

5.2 Monitoring in de beheerfase 33

6 Conclusies $\quad 35$

$\begin{array}{lll}7 & \text { Literatuur } & 36\end{array}$

8 Bijlagen $\quad 37$

8.1 Bijlage 1: Ecologie van de gewone veenmoerassteekmug (Aedes cinereus) $\quad 37$

8.2 Bijlage 12: Ecologie van de belangrijkste soorten knutten 39 


\section{Inleiding}

\subsection{Aanleiding en vraag}

In opdracht van Staatsbosbeheer is in de periode 2015-2020 door Wageningen Environmental Research (WEnR) onderzoek uitgevoerd naar stekende insecten in en rondom het dorp Griendtsveen. Om de klachten van de bewoners van het dorp Griendtsveen over overlast door steekmuggen te onderzoeken is in 2014 een risico-analyse uitgevoerd en is in $\mathbf{2 0 1 5}$ gestart met het monitoren van stekende insecten. Al snel werd duidelijk dat de gesignaleerde overlast door moerassteekmuggen (voornamelijk de veenmoerassteekmug Aedes cinereus) werd veroorzaakt. Deze steekmuggen zijn afkomstig uit de Pelen (Mariapeel, de Deurnsche Peel, het Kanaalbos en het Grauwveen) die het dorp aan de oost-, zuid- en westzijde omringen. De moerassteekmuggen ontwikkelen zich in langdurig water bevattende depressies zoals poeltjes en uitdrogende slenken en greppels. De moerassteekmuggen verspreiden zich na het uitvliegen over de omgeving, onder andere in de richting van het dorp. De milieuomstandigheden, al dan niet als gevolg van menselijk handelen, in de natuurgebieden die het dorp omringen kunnen bijgedragen hebben aan een toename van steekmuggen in het dorp. Daarnaast kunnen ook huissteekmuggen voorkomen afkomstig uit de nabije omgeving van de woningen.

De resultaten van de risico-analyse in 2014 gaven onder andere aan dat de voorgenomen LIFE+ maatregelen in de Mariapeel bij zouden kunnen dragen aan een vermindering van de aantallen moerassteekmuggen, mits deze bij de uitvoering ook leiden tot vermindering van het oppervlak aan langdurig tijdelijke wateren. Daarom is door de adviescommissie Mariapeel het besluit genomen om de maatregelen van het LIFE+ project in de Mariapeel zo uit te voeren dat de overlast door moerassteekmuggen wordt teruggedrongen. De Life+ maatregelen zijn in het voorjaar van 2018 afgerond.

Om tijdens de uitvoering van de maatregelen de ontwikkelingen in de populaties van stekende insecten te volgen zijn vanaf 2015 jaarlijks de volwassen steekmuggen gemonitord en is aandacht gegeven aan de plaatsen waar de larven mogelijk opgroeien, de zogenaamde broedgebieden. De belangrijkste vragen bij het onderzoek waren:

- Hoe ontwikkelen de moerassteekmuggen zich in en rondom het dorp Griendtsveen gedurende de uitvoering van het LIFE+ project en in de jaren daarna?

- Waar liggen in een zone van 2 kilometer rond het dorp Griendtsveen de broedplaatsen van de overlast veroorzakende moerassteekmuggen?

- Welke sturingsmechanismen in de waterhuishouding om de ontwikkeling van broedplaatsen in de moerasgebieden gedurende de looptijd van het LIFE+ project tegen te gaan zijn er?

- Kunnen de direct overlast veroorzakende gebiedsdelen (zgn. 'hotspots') op korte termijn worden aangepakt?

Jaarlijks is over de toestand gerapporteerd en waar nodig is geadviseerd om de uitvoering van de maatregelen zo in te richten dat ze aansloten op het doel om overlast van stekende insecten te voorkomen.

De periode van uitvoering van maatregelen, de zogenaamde nul- of maatregelfase, liep in 2020 af. WEnR is gevraagd om de onderzoeksresultaten te bundelen en in een eindrapport te evalueren met het doel de volgende vragen te beantwoorden:

- Wat is de uitgangssituatie (nul- of maatregelfase) op basis van de meetgegevens van 2015-2020 met de nadruk op de relatie stekende insecten - natheid gebied - weer?

- Wanneer is sprake van overlast in het natuurgebied en in het dorp?

- Zijn er (extra) richtlijnen nodig voor het beheer op basis van de evaluatie met speciale aandacht voor opties om tussentijds bij te stellen? En Wat zijn passende maatregelen mochten er broedplaatsen ontstaan?

- Hoe ziet de monitoring in de beheerfase eruit die start vanaf 2023 en daarna iedere 2-3 jaar afhankelijk van ontwikkelingen herhaald zou kunnen worden?

\subsection{Doel}

Het hoofddoel van het project is het terugdringen van de steekmuggenoverlast in Griendtsveen. Om dit doel te bereiken zijn een aantal onderzoeken uitgevoerd: 
- Het uitvoeren van reguliere monitoring in ruimte en tijd om de ontwikkelingen en eventuele overlast van stekende insecten in en rondom het dorp Griendtsveen vast te leggen.

- Het in kaart brengen van langdurig tijdelijke wateren die functioneren als broedplaats voor moerassteekmuggen om op basis van de aldaar aanwezige gebiedshydrologie en -morfologie doelgerichte maatregelen te kunnen formuleren om deze broedplaatsen in oppervlak te verminderen.

- Het op basis van de meetresultaten aan larven en volwassen stekende insecten adviseren over eventuele aanpassingen in en aanvullingen op het maatregelenpakket van LIFE+ in de Mariapeel en het na uitvoering van die maatregelen adviseren over met name het peilbeheer om de het optreden van langdurig tijdelijke wateren te verminderen.

- Het adviseren over eventuele maatregelen t.a.v. de verbindingszones waarlangs volwassen moerassteekmuggen zouden kunnen migreren van het natuurgebied naar het dorp m.a.w. ze zo in te richten dat deze dienen als barrières i.p.v. corridors voor stekende insecten. 


\section{Ontwikkelingen van stekende insecten van 2015 tot en met 2020}

\subsection{Volwassen steekmuggen}

In dit hoofdstuk wordt de uitgangssituatie (nul- of maatregelfase) op basis van de meetgegevens uit de periode van 2015 tot en met 2020 beschreven. Hierbij wordt de nadruk in de analyses gelegd op de relaties tussen de (potentieel) overlast veroorzakende steekmuggen, de natheid van het natuurgebied en het weer.

Tijdens de zes jaar monitoring van steekmuggen in de maanden april (in 2015 vanaf mei) tot en met september op (meestal) 18 locaties springen er 3 jaren uit met zeer hoge aantallen: 2016, 2018 en 2020 (Figuur 2.1). In 2016 traden de hoogste aantallen op in juli terwijl in 2018 en 2020 dat in respectievelijk mei en in mei-juni was.

De hoge aantallen in 2018 en 2020 betroffen moerassteekmuggen en met name soorten uit het geslacht Aedes, beide andere geslachten die behoren tot de moerassteekmuggen, Ochlerotatus en Culiseta (Culicella), waren veel minder talrijk (Figuur 2.2). Het geslacht Ochlerotatus neemt tot circa $10 \%$ van de populatie moerassteekmuggen in en de dichtheid wisselde minder tussen de jaren dan die van de vertegenwoordigers van het geslacht Aedes. In 2016 betrof de piek in aantallen de huissteekmug uit het geslacht Culex (Figuur 2.3). Van de huissteekmuggen kwamen naast soorten uit het geslacht Culex ook vertegenwoordigers uit het geslacht Culiseta (Culiseta) voor.

De twee andere geslachten van steekmuggen in het gebied zijn de plantenboorsteekmuggen (Coquillettidia) en de slootsteekmuggen (Anopheles). Hun aantallen waren veel lager t.o.v. de moeras- en huissteekmuggen (Figuur 2.4; let op de schaal van de $\mathrm{Y}$-as is kleiner) en hun voorkomen is over de jaren veel constanter.

Het soms in hoge aantallen voorkomen van steekmuggen betrof het geslacht Aedes in het voorjaar en Culex in de zomer.

Van het geslacht Culex kwamen drie soorten voor: Culex modestus, Culex pipiens complex en Culex territans. Van deze drie soorten nam het Culex pipiens complex bijna $99 \%$ van het aantal individuen in. Dus de soort Culex pipiens complex is bij eventueel optreden van overlast in de zomer de belangrijkste aandachtsoort.

Het geslacht Aedes is aanwezig met twee soorten Aedes cinereus (veenmoerassteekmug) en Aedes vexans, waarvan de laatste $0.015 \%$ van het totaal aan individuen innam. Dus de soort Aedes cinereus is bij eventueel optreden van overlast in het voorjaar de belangrijkste en enige aandachtsoort. Het vervolg van deze rapportage richt zich hoofdzakelijk op deze soort. 


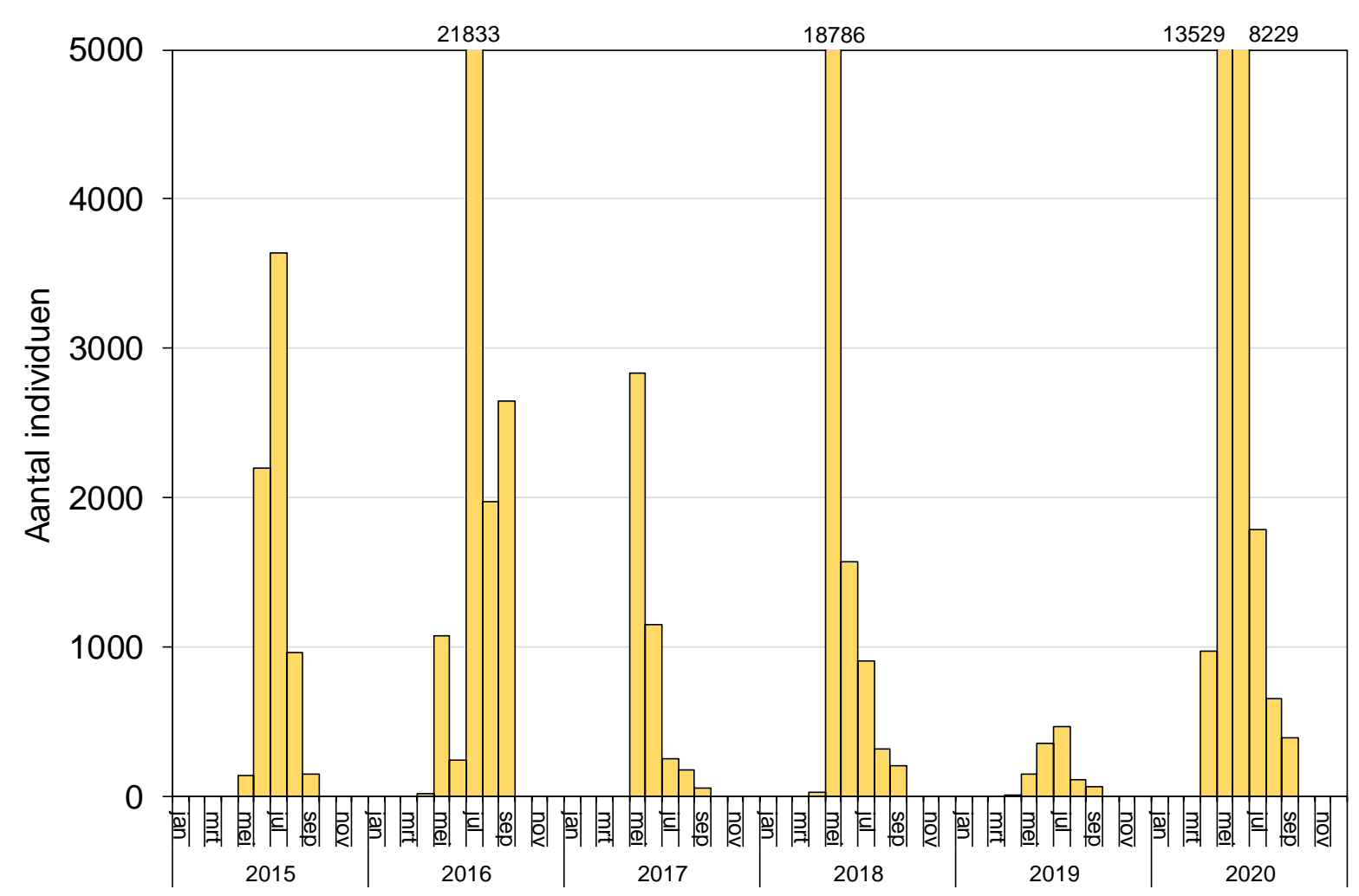

Figuur 2.1: Het aantal individuen van volwassen steekmuggen per maand over de jaren 2015-2020.

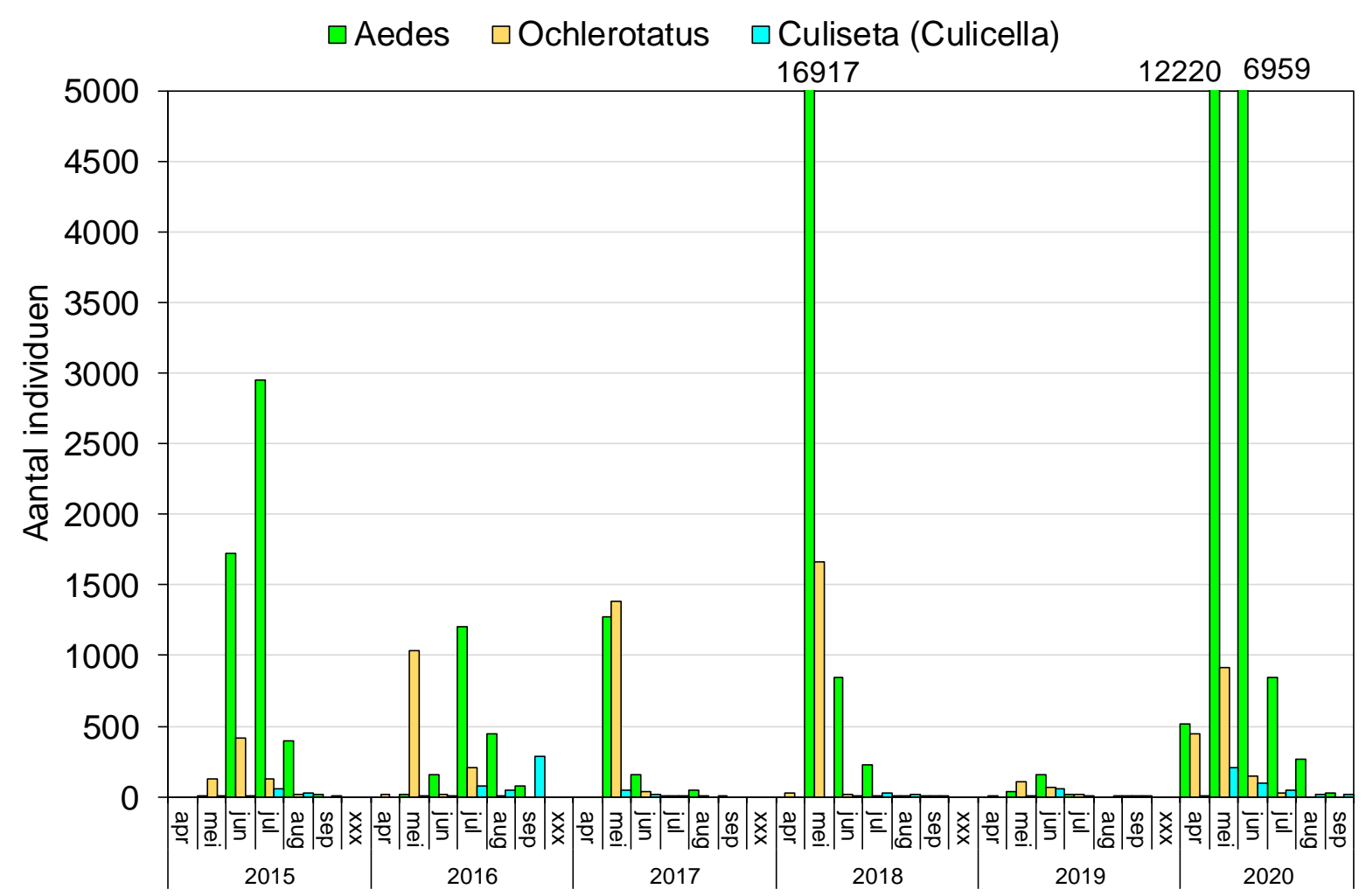

Figuur 2.2: Het aantal individuen van volwassen moerassteekmuggen per maand over de jaren 20152020. 


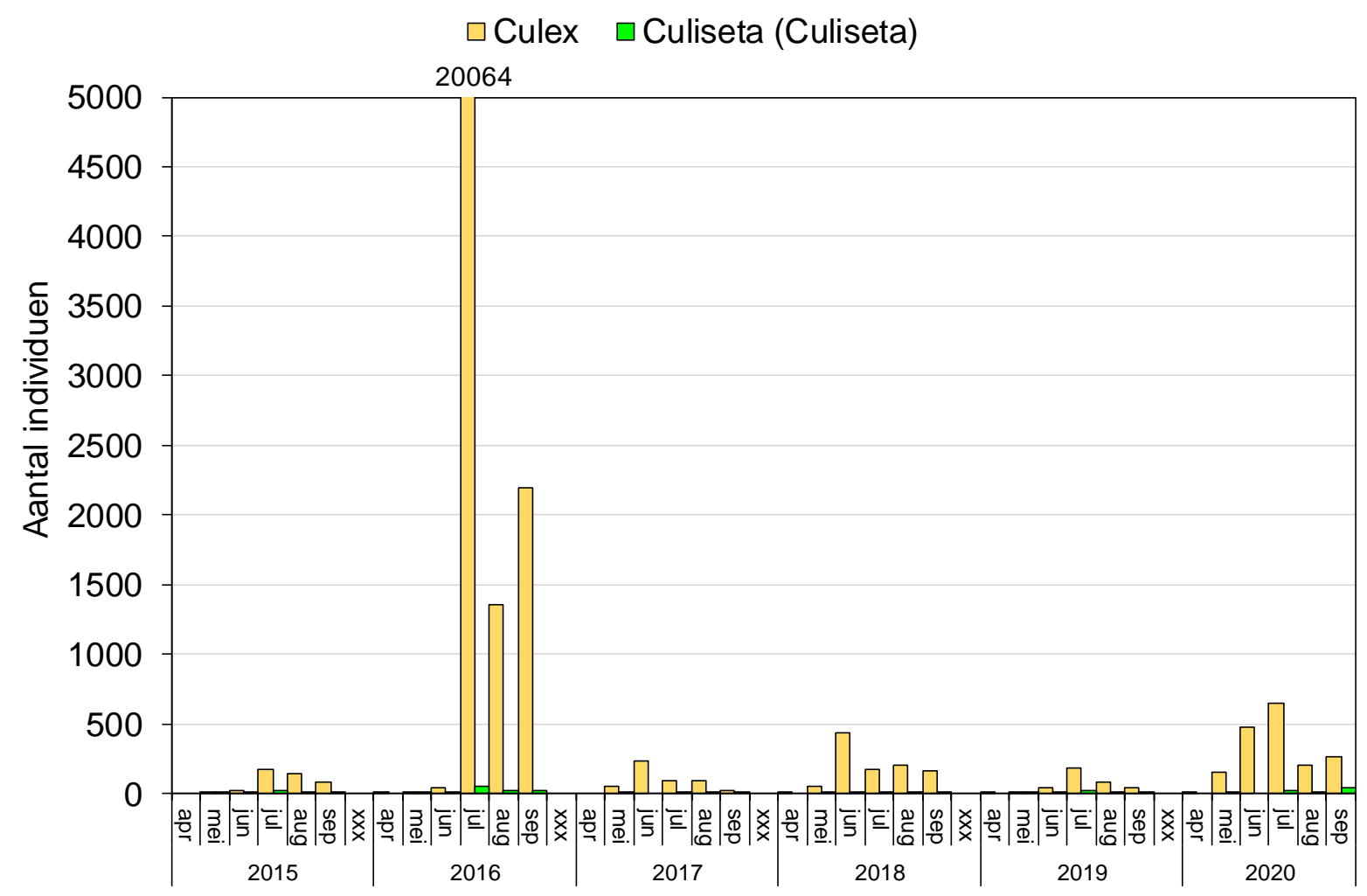

Figuur 2.3: Het aantal individuen van volwassen huissteekmuggen per maand over de jaren 2015-2020.

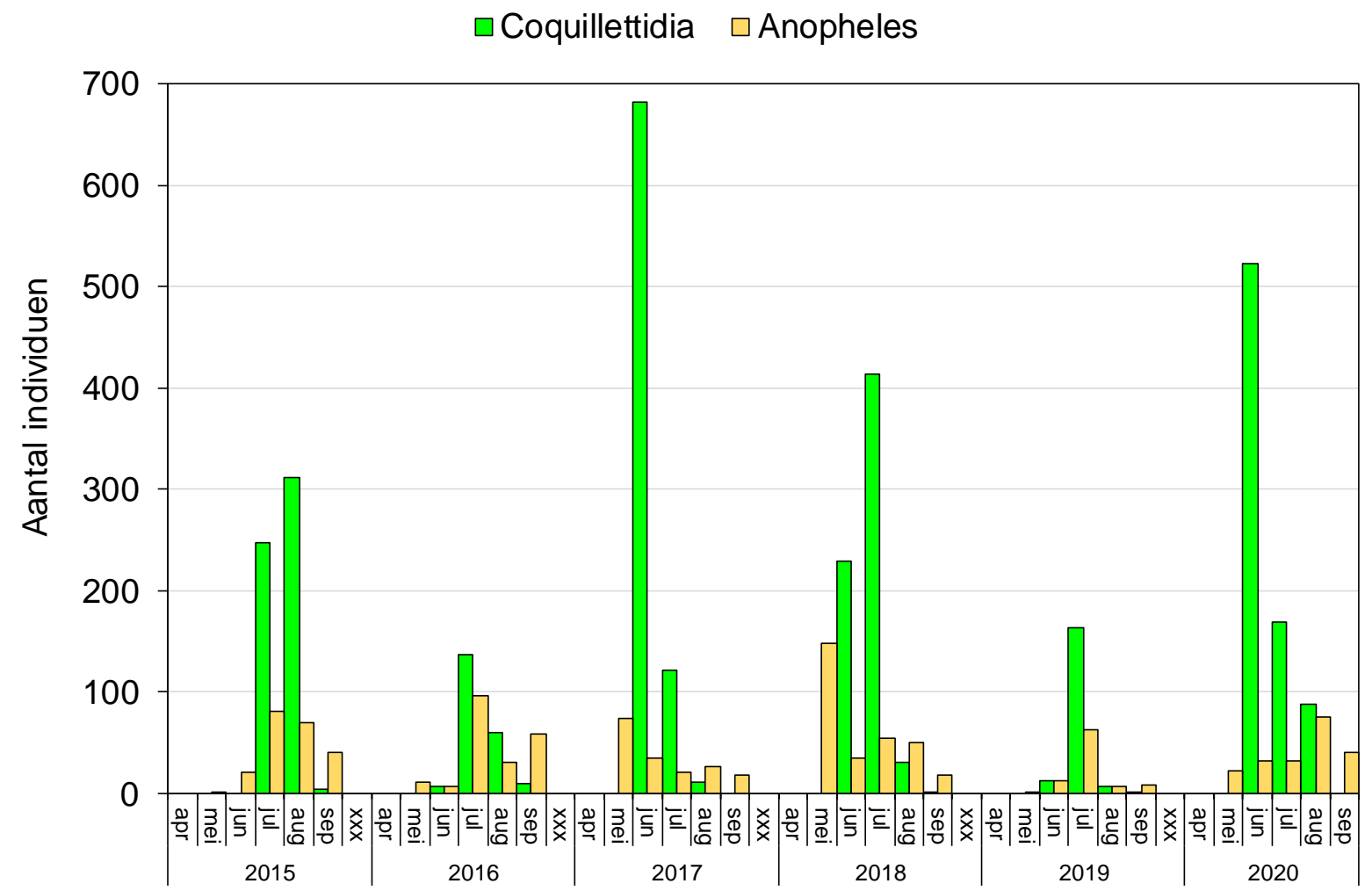

Figuur 2.4: Het aantal individuen van volwassen plantenboor- en slootsteekmuggen per maand over de jaren 2015-2020. 


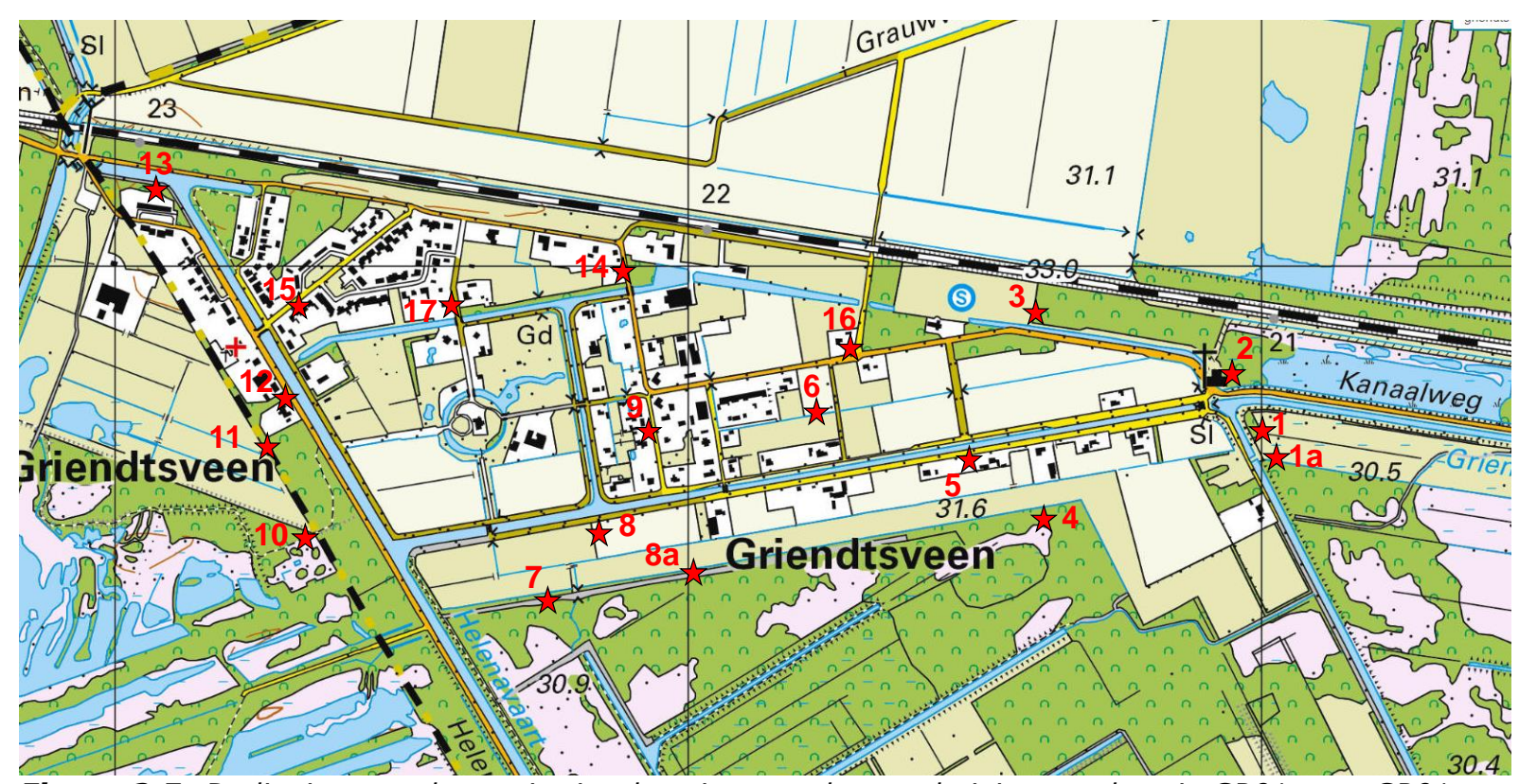

Figuur 2.5: De ligging van de monitoringslocaties met de verschuiving van locatie GRO1 naar GRO1a en van GR08 naar GR08a.

Naast de aantallen individuen van volwassen steekmuggen is ook gekeken naar de ruimtelijke verdeling. Locatie 1 (GR01) is in 2017 iets naar het zuiden verplaatst (Figuur 2.5) wat een relatief grotere vangst opleverde van $6.8 \%$ naar $13.2 \%$ in de periode $2015-2016$ t.o.v. 2017-2020 (Figuur 2.6). Locatie 8 (GR08) is in 2020 verschoven omdat de eerder aanwezige coniferenhaag volledig was verdwenen. De locatie is verlegd richting het natuurgebied en hierdoor is de vangst in 2020 t.o.v. voorgaande jaren sterk toegenomen van $3.3 \%$ naar $14.4 \%$ (Figuur 2.6 ).

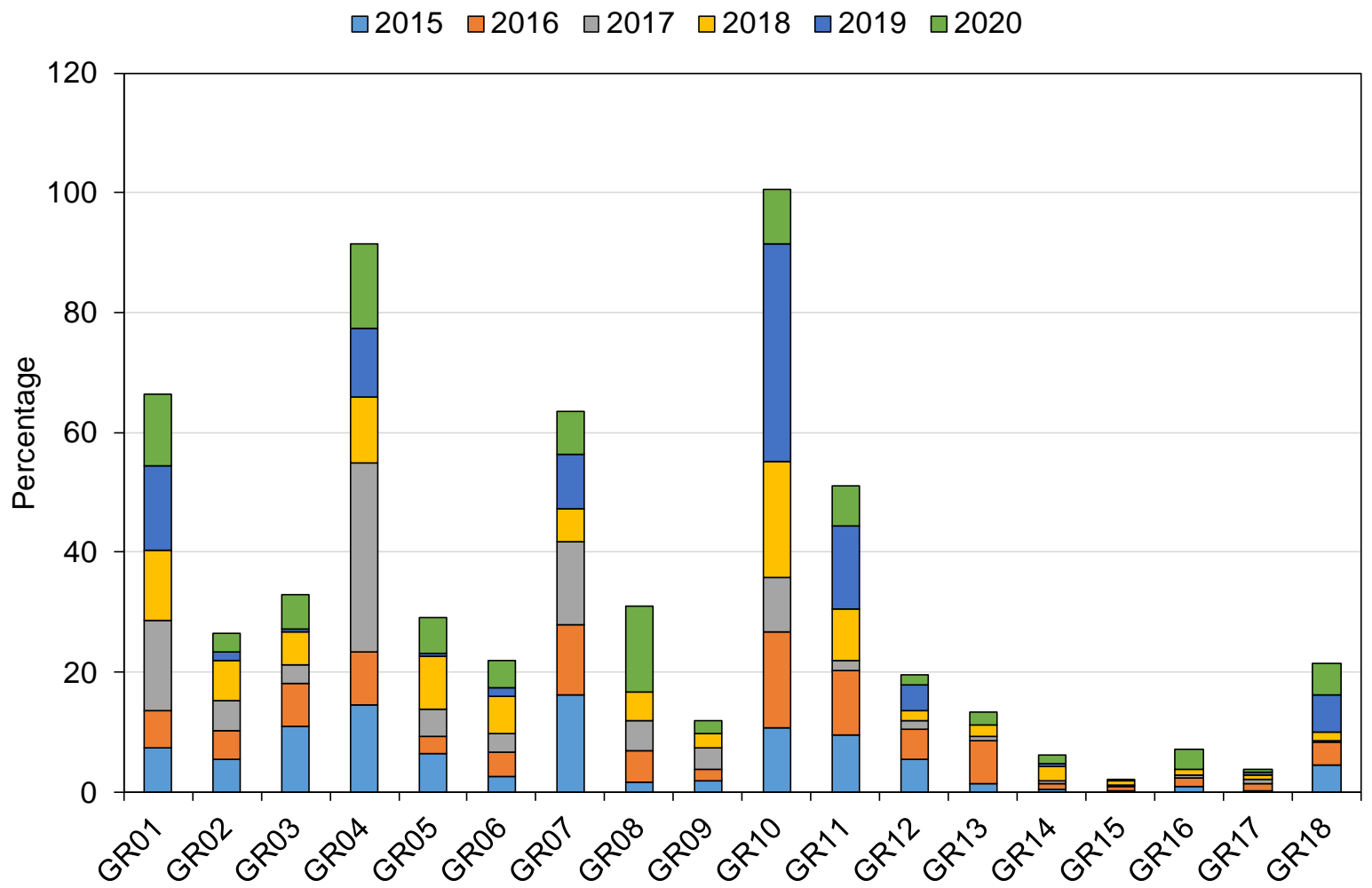

Figuur 2.6: De procentuele verdeling van het aantal individuen van de veenmoerassteekmug $A$. cinereus per locatie per jaar over de periode 2015-2020. 


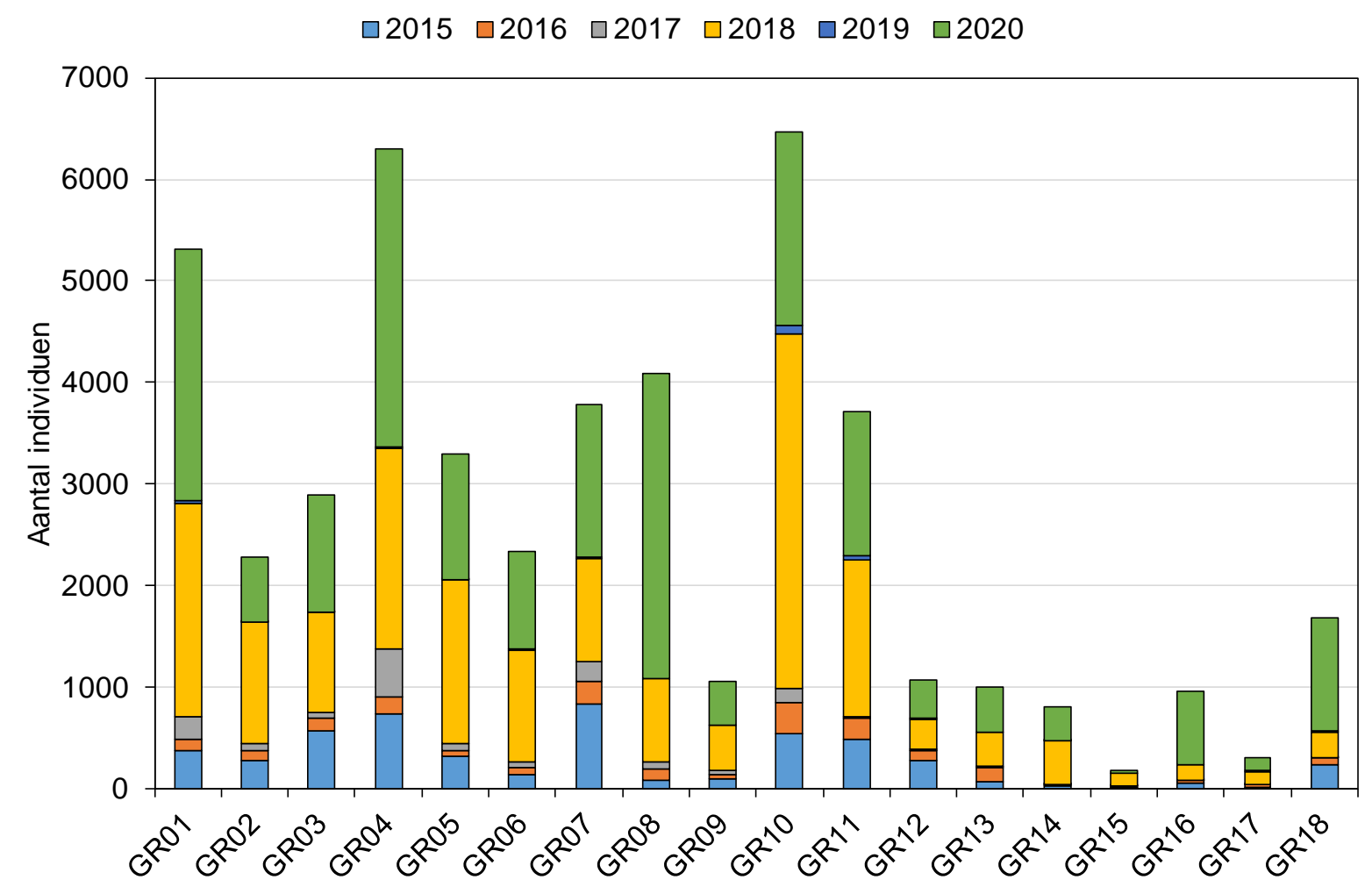

Figuur 2.7: Het aantal individuen van A. cinereus per locatie per jaar over de periode 2015-2020.

De absolute aantallen van de veenmoerassteekmug ( $A$. cinereus) laten zien dat de locaties GR01, GR04, GR08 in 2020 en GR10 er uit springen met de hoogste aantallen (Figuur 2.7). Het betreft allemaal locaties aan de noordrand van het natuurgebied en ten zuiden van het dorp. De enige uitzondering met iets lagere aantallen is locatie GR07 die samen met GR11 procentueel wel een belangrijk aandeel in de totale aantallen heeft maar absoluut iets lager liggen. De verschillen kunnen een gevolg zijn van lokale milieuomstandigheden (bijvoorbeeld minder dichte begroeiing) of iets drogere omgeving. Dan volgt een groep van locaties, GR02, GR03, GR05 en GR06, met lagere aantallen t.o.v. de voorgaande locaties en die in de oostzijde en meer naar het dorp toe liggen. Hierin neemt locatie GR16 een andere positie in met lage aantallen tezamen met de locaties GR09, GR12, GR13 en GR14, allemaal locaties bij bewoning en in het dorp. Zeer laag waren de aantallen op de centraal in het dorp gelegen locaties GR15 en GR17.

\subsection{Larven van de veenmoerassteekmug (A. cinereus)}

In totaal zijn in de periode 2016-2020 66951 dips genomen op 1274 locaties, waarvan een deel als herhalingen in de tijd (in 2015 zijn geen metingen naar larven uitgevoerd). Opvallend is dat het aandeel van de steekmuglarven uit het genus Ochlerotatus veel hoger is dan die uit het genus Aedes (Tabel 2.1). Beide geslachten zijn het meest verzameld in de maand april, echter $O$. punctor verschijnt als larf al in maart. Ook de habitat van beide taxa is vergelijkbaar alhoewel 0 . punctor voor $88 \%$ (tegenover $61 \%$ voor A. cinereus) voorkwam in half-open tot gesloten bos met pijpenstrootje als ondergroei. Ochlerotatus groeit al vroeg in het voorjaar op tot volwassen steekmug. Het zou kunnen dat hierdoor tijdens de dip-campagnes meer grote larven die al in de laatste stadia verkeerden zijn gedipt. Omdat de potentieel overlast veroorzakende steekmuggen tot de soort $A$. cinereus behoren wordt het genus Ochlerotatus niet nader beschouwd.

Tijdens het dippen zijn steeds een aantal milieuparameters opgenomen. Om de habitat van de veenmoerassteekmug beter te duiden zijn hierop analyses verricht. $A$. cinereus verschijnt talrijk in april en is vooral verzameld in poeltjes drassig tot enkeldiep (diepte van 1 tot $20 \mathrm{~cm}$; Figuur 2.8). 
Tabel 2.1: Het aantal en percentage larven verzameld over de periode 2016-2020 in de zone van 2 km rondom het dorp Griendtsveen.

\begin{tabular}{lll}
\hline Taxon & Totaal aantal \# & Percentage \\
\hline Aedes cinereus & 8988 & 29.0 \\
Aedes/Ochlerotatus & 11 & 0.0 \\
Culex & 438 & 1.4 \\
Culex pipiens & 22 & 0.1 \\
Culex territans & 1 & 0.0 \\
Culiseta & 67 & 0.2 \\
Culiseta annulata & 132 & 0.4 \\
Culiseta morsitans & 143 & 0.5 \\
Ochlerotatus & 3472 & 11.2 \\
Ochlerotatus annulipes & 21 & 0.1 \\
Ochlerotatus cantans & 1694 & 5.5 \\
Ochlerotatus cantans/annulipes & 244 & 0.8 \\
Ochlerotatus flavescens & 1134 & 3.7 \\
Ochlerotatus nigrinus & 4 & 0.0 \\
Ochlerotatus punctor & 14654 & 47.2 \\
Ochlerotatus rusticus & 2 & 0.0 \\
\hline Totaal & $\mathbf{3 1 0 2 4}$ & \\
\hline & &
\end{tabular}

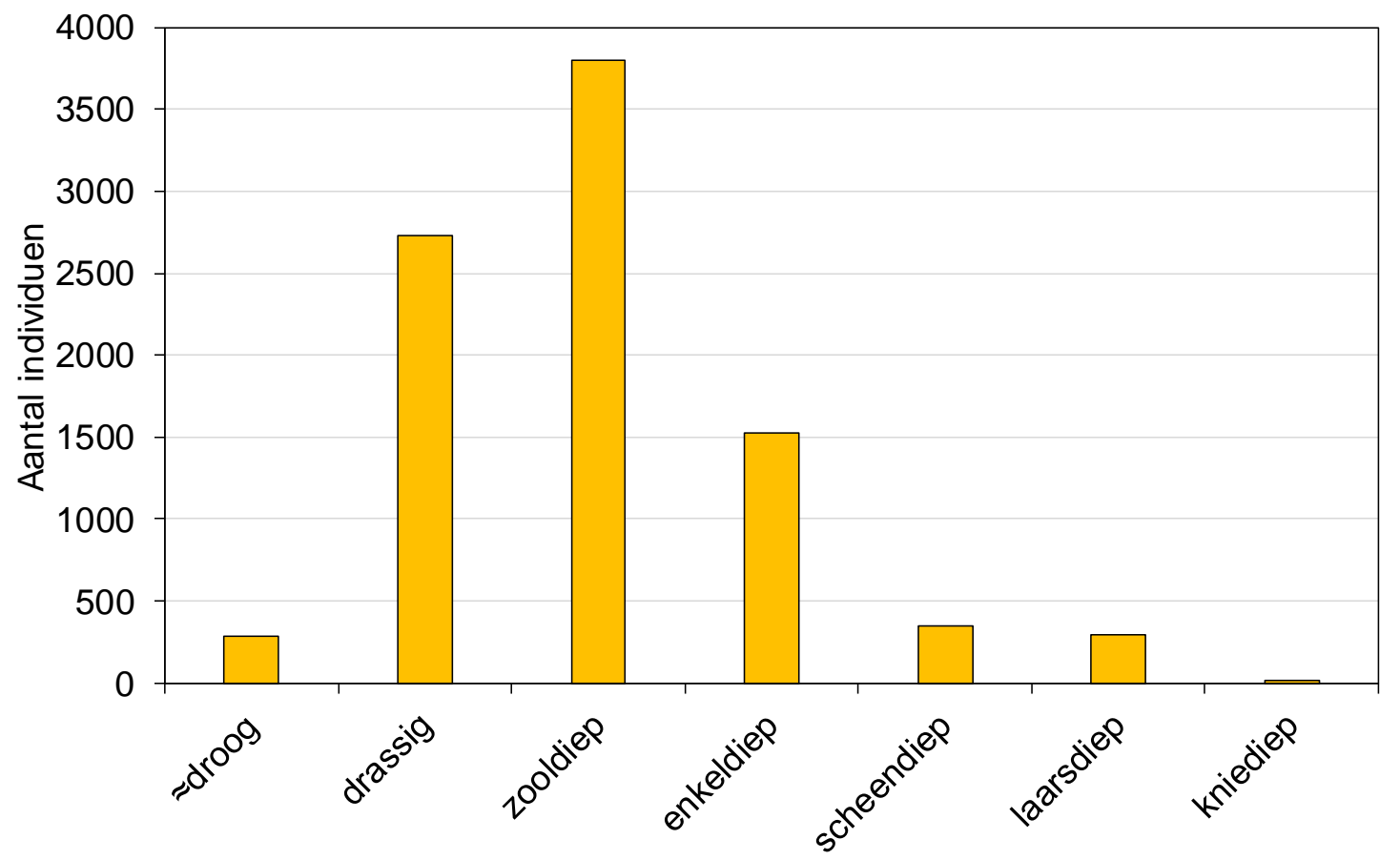

Figuur 2.8: Het aantal larven van de veenmoerassteekmug ( $A$. cinereus) per waterdiepteklasse ( $\approx$ droog $=0-1 \mathrm{~cm}$, drassig $1-5 \mathrm{~cm}$, zooldiep 5-10cm, enkeldiep $10-20 \mathrm{~cm}$, scheendiep $20-35 \mathrm{~cm}$, laarsdiep $35-50 \mathrm{~cm}$, kniediep 50-100cm) gebaseerd op alle monsters uit 2016-2020. 
Tabel 2.2: Som van het aantal individuen (som) met aantal waarnemingen ( $n$ ) en gemiddelde ( $g$ emid.) met standaardafwijking (std) van de larven van de veenmoerassteekmug (A. cinereus) per begroeiingstype (boven- en ondergroei) en mate van beschaduwing.

\begin{tabular}{|c|c|c|c|c|c|c|c|c|c|c|c|c|c|c|c|c|c|}
\hline 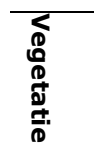 & 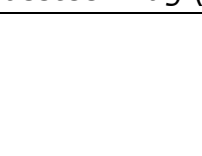 & 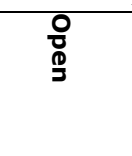 & 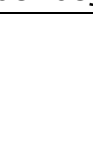 & $\begin{array}{l}\text { W } \\
\frac{\mathrm{T}}{\lambda} \\
\end{array}$ & 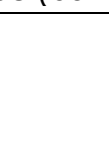 & $\frac{\mathrm{m}}{\mathrm{m}}$ & $\underline{\Xi}$ & 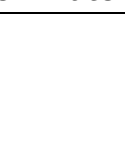 & $\begin{array}{l}\vec{a} \\
\frac{a}{0} \\
\frac{\Phi}{m} \\
\frac{m}{n}\end{array}$ & & 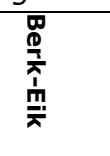 & & 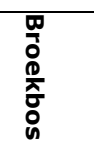 & & $\begin{array}{l}\stackrel{0}{0} \\
\stackrel{0}{0} \\
\stackrel{3}{0}\end{array}$ & 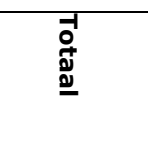 & \\
\hline \multirow[t]{4}{*}{ 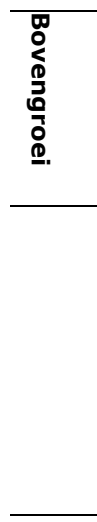 } & 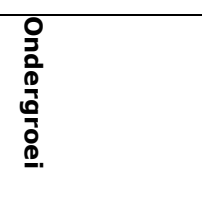 & $\frac{n}{3}$ & 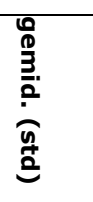 & $\frac{n}{3}$ & 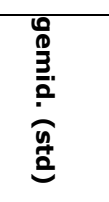 & 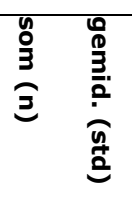 & $\frac{\stackrel{0}{3}}{3}$ & 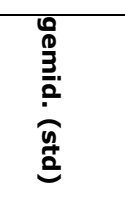 & 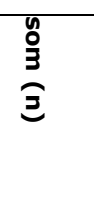 & 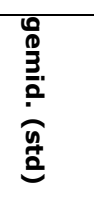 & 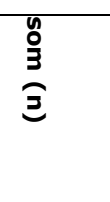 & 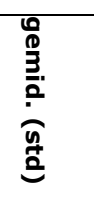 & $\frac{n}{3}$ & 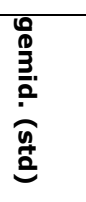 & 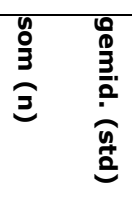 & $\stackrel{\frac{n}{3}}{3}$ & 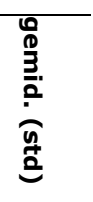 \\
\hline & Gras & $5(1)$ & & & & & & & & & & & & & & $5(1)$ & \\
\hline & Pitrus & $352(22)$ & $\begin{array}{r}16 \\
(15)\end{array}$ & & & & & & & & & & & & & $352(22)$ & $\begin{array}{r}16 \\
(15)\end{array}$ \\
\hline & $\begin{array}{l}\text { Moeras- } \\
\text { vegetatie }\end{array}$ & $5(1)$ & & & & & & & & & & & & & & $5(1)$ & \\
\hline \multirow[t]{7}{*}{ Open } & Subtotaal & $\begin{array}{r}1052 \\
(70)\end{array}$ & $\begin{array}{r}15 \\
(20) \\
\end{array}$ & $215(3)$ & $\begin{array}{r}72 \\
(59) \\
\end{array}$ & & & & & & $30(1)$ & & & & & $1296(74)$ & $\begin{array}{r}18 \\
(24) \\
\end{array}$ \\
\hline & Geen & $22(3)$ & $7(5)$ & $8(1)$ & & & & & & & $58(1)$ & & $6(1)$ & & & $94(6)$ & $\begin{array}{r}16 \\
(21)\end{array}$ \\
\hline & Pitrus & $74(3)$ & $\begin{array}{r}25 \\
(32)\end{array}$ & $157(11)$ & $\begin{array}{r}14 \\
(13)\end{array}$ & & $\begin{array}{l}317 \\
(12)\end{array}$ & $26(26)$ & $1(1)$ & & $8(1)$ & & & & & $556(28)$ & $\begin{array}{r}20 \\
(21)\end{array}$ \\
\hline & Varens & & & $12(1)$ & & & & & & & & & & & & $12(1)$ & \\
\hline & Ruigte & & & & & & & & & & & & $8(1)$ & & & $8(1)$ & \\
\hline & $\begin{array}{l}\text { Moeras- } \\
\text { vegetatie }\end{array}$ & $5(1)$ & & $20(2)$ & $10(7)$ & & $15(2)$ & $8(4)$ & & & & & & & & $40(5)$ & $8(4)$ \\
\hline & Overig & & & & & & & & $\begin{array}{l}13 \\
(1) \\
\end{array}$ & & & & & & & $13(1)$ & \\
\hline \multirow[t]{2}{*}{$\begin{array}{l}\text { Half } \\
\text { open }\end{array}$} & Subtotaal & $672(29)$ & $\begin{array}{r}23 \\
(21) \\
\end{array}$ & $\begin{array}{r}2879 \\
(107) \\
\end{array}$ & $\begin{array}{r}27 \\
(45) \\
\end{array}$ & & $\begin{array}{r}416 \\
(19) \\
\end{array}$ & $22(22)$ & $\begin{array}{r}28 \\
(4) \\
\end{array}$ & $7(7)$ & $\begin{array}{r}572 \\
(14) \\
\end{array}$ & $\begin{array}{r}41 \\
(34) \\
\end{array}$ & $\begin{array}{l}14 \\
(2) \\
\end{array}$ & $7(1)$ & & $\begin{array}{r}4580 \\
(175) \\
\end{array}$ & $\begin{array}{r}26 \\
(38) \\
\end{array}$ \\
\hline & Geen & $5(2)$ & $5(2)$ & $110(6)$ & $\begin{array}{r}18 \\
(20)\end{array}$ & & & & & & $39(4)$ & $10(7)$ & $\begin{array}{c}35 \\
(5)\end{array}$ & $7(5)$ & & 188 (17) & $\begin{array}{r}11 \\
(13)\end{array}$ \\
\hline
\end{tabular}




\begin{tabular}{|c|c|c|c|c|c|c|c|c|c|c|c|c|c|c|c|c|c|c|}
\hline 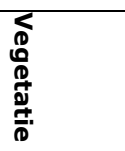 & & $\begin{array}{l}\text { Oे } \\
\text { D্ } \\
3\end{array}$ & & $\begin{array}{l}\text { W } \\
\frac{\mathbb{0}}{\lambda}\end{array}$ & & $\frac{\mathrm{m}}{\mathrm{m}}$ & $\sum$ & & 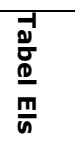 & & 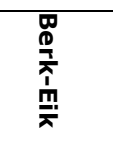 & & 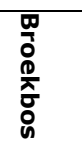 & & 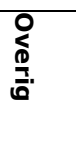 & & 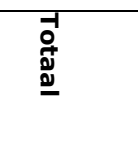 & \\
\hline \multirow[t]{9}{*}{ 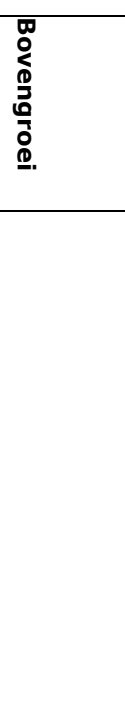 } & 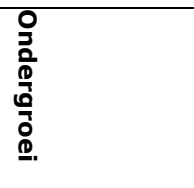 & $\begin{array}{l}\begin{array}{l}n \\
0 \\
3 \\
3\end{array} \\
3\end{array}$ & $\begin{array}{l}0 \\
0 \\
0 \\
3 \\
0 \\
\vdots \\
\frac{0}{0} \\
0\end{array}$ & $\begin{array}{l}\frac{1}{0} \\
\vdots \\
3 \\
3\end{array}$ & 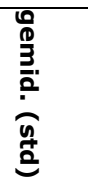 & 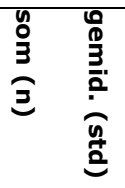 & $\begin{array}{l}\frac{1}{0} \\
\vdots \\
3 \\
3\end{array}$ & 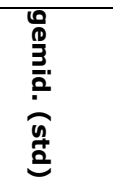 & $\begin{array}{l}\text { y } \\
\vdots \\
3 \\
\Xi\end{array}$ & 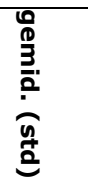 & $\begin{array}{l}\frac{y}{0} \\
\vdots \\
3 \\
\Xi\end{array}$ & $\begin{array}{l}0 \\
0 \\
0 \\
3 \\
0 \\
\vdots \\
\frac{0}{0} \\
0\end{array}$ & $\begin{array}{l}n \\
0 \\
3 \\
3\end{array}$ & 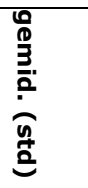 & $\begin{array}{l}\begin{array}{l}n \\
0 \\
3 \\
3\end{array} \\
3\end{array}$ & $\begin{array}{l}0 \\
0 \\
03 \\
30 \\
\vdots 0 \\
\frac{0}{0} \\
0\end{array}$ & $\begin{array}{l}0 \\
0 \\
3 \\
3\end{array}$ & 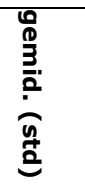 \\
\hline & Gras & $31(6)$ & $5(3)$ & $13(2)$ & $6(5)$ & & $10(1)$ & & & & $35(3)$ & $12(4)$ & $2(1)$ & & & & $91(13)$ & $7(4)$ \\
\hline & Veenmos & $64(1)$ & & & & & $104(5)$ & $21(24)$ & & & & & $\begin{array}{r}34 \\
(4)\end{array}$ & $9(6)$ & & & $203(10)$ & $\begin{array}{r}20 \\
(23)\end{array}$ \\
\hline & Pijpenstrootje & $346(34)$ & $\begin{array}{r}10 \\
(11)\end{array}$ & $1192(69)$ & $\begin{array}{r}17 \\
(22)\end{array}$ & & $339(3)$ & $\begin{array}{r}113 \\
(135)\end{array}$ & $\begin{array}{r}78 \\
(2)\end{array}$ & $\begin{array}{r}39 \\
(34)\end{array}$ & $234(5)$ & $\begin{array}{r}47 \\
(94)\end{array}$ & & & $\begin{array}{l}28 \\
(1)\end{array}$ & & $\begin{array}{r}2217 \\
(114)\end{array}$ & $\begin{array}{r}19 \\
(36)\end{array}$ \\
\hline & Pitrus & $6(3)$ & $2(3)$ & $57(8)$ & $7(5)$ & & $104(6)$ & $17(16)$ & & & & & $\begin{array}{l}73 \\
(2)\end{array}$ & $\begin{array}{r}36 \\
(44)\end{array}$ & & & 239 (19) & $\begin{array}{r}13 \\
(17)\end{array}$ \\
\hline & Varens & & & $1(1)$ & & $\begin{array}{r}1 \\
(1)\end{array}$ & & & & & $12(2)$ & $6(1)$ & & & & & $14(4)$ & $4(3)$ \\
\hline & Ruigte & & & & & & & & & & $16(4)$ & $4(3)$ & & & & & $16(4)$ & $4(3)$ \\
\hline & $\begin{array}{l}\text { Moeras- } \\
\text { vegetatie }\end{array}$ & & & $78(2)$ & $\begin{array}{r}39 \\
(54)\end{array}$ & & $30(1)$ & & & & $5(1)$ & & & & & & $113(4)$ & $\begin{array}{r}28 \\
(35)\end{array}$ \\
\hline & Overig & $9(1)$ & & $14(2)$ & $7(8)$ & & $6(1)$ & & & & $2(2)$ & $1(0)$ & & & & & $31(6)$ & $5(5)$ \\
\hline Gesloten & Subtotaal & $\begin{array}{r}462 \\
(47)\end{array}$ & $\begin{array}{r}10 \\
(13)\end{array}$ & $\begin{array}{r}1464 \\
(90)\end{array}$ & $\begin{array}{r}16 \\
(21)\end{array}$ & $\begin{array}{r}1 \\
(1)\end{array}$ & $\begin{array}{r}593 \\
(17)\end{array}$ & $\begin{array}{r}35 \\
(63)\end{array}$ & 78 & $\begin{array}{r}39 \\
(34)\end{array}$ & $\begin{array}{r}343 \\
(21)\end{array}$ & $\begin{array}{r}16 \\
(46)\end{array}$ & $\begin{array}{c}144 \\
(12)\end{array}$ & $\begin{array}{r}12 \\
(18)\end{array}$ & 28 & & 3113 & 16 \\
\hline Totaal & & $\begin{array}{r}2185 \\
(146)\end{array}$ & $\begin{array}{r}15 \\
(19)\end{array}$ & $\begin{array}{r}4558 \\
(200)\end{array}$ & $\begin{array}{r}23 \\
(37)\end{array}$ & $\begin{array}{r}1 \\
(1)\end{array}$ & $\begin{array}{r}1009 \\
(36)\end{array}$ & $\begin{array}{r}28 \\
(46)\end{array}$ & $\begin{array}{r}106 \\
(6)\end{array}$ & $\begin{array}{r}18 \\
(23)\end{array}$ & $\begin{array}{r}945 \\
(36)\end{array}$ & $\begin{array}{r}26 \\
(42)\end{array}$ & $\begin{array}{r}157 \\
(14)\end{array}$ & $\begin{array}{r}11 \\
(17)\end{array}$ & $\begin{array}{l}28 \\
(1)\end{array}$ & & $\begin{array}{r}8988 \\
(440)\end{array}$ & $\begin{array}{r}20 \\
(33)\end{array}$ \\
\hline
\end{tabular}


De larven prefereerden vooral half-open tot gesloten berken- $(51 \%)$, wilgen- $(11 \%)$ of berken-eikenbos (11\%) met voornamelijk pijpenstrootje als ondergroei. Slechts $24 \%$ was aanwezig in open landschap, voornamelijk in pijpenstrootje begroeiing (Tabel 2.2). De tijdens de inventarisaties opgenomen schatting van het oppervlakte nat in een deelgebied en de mate van permanentie van de betreffende poelen leverden een grote en gelijkmatige spreiding van aantallen over alle klassen op. De omvang van de poeltjes of het vlak met onderling min of meer verbonden poeltjes is bijna $1 \mathrm{~m}^{2}$. Het water is zuur en heeft een laag elektrisch geleidend vermogen (EGV) (Tabel 2.3). Daarnaast bleek dat dergelijke schattingen over tijd of over grote ruimtelijke arealen moeilijk uitvoerbaar waren.

Tabel 2.3: Enkele kwantitatieve waarden van milieuparameters opgenomen tijdens de larven inventarisaties in de periode 2016-2020.

\begin{tabular}{lllll}
\hline & Lengte $\mathbf{( c m})$ & Breedte $\mathbf{( c m )}$ & pH & EGV $\boldsymbol{\mu S}$ \\
\hline Gemiddelde waarde & 84 & 107 & 4.0 & 138 \\
Standaardafwijking & 97 & 117 & 0.8 & 56 \\
Aantal waarnemingen & 94 & 94 & 95 & 90 \\
\hline
\end{tabular}

De ruimtelijke verdeling van larvale broedplaatsen is in de periode 2016-2020, afhankelijk van de mogelijkheden, soms weinig intensief en soms zeer intensief uitgevoerd. Dergelijke inventarisaties zijn tot op heden nog steeds zeer arbeidsintensief en moeten onder lastige, moeilijk toegankelijke gebiedsomstandigheden worden uitgevoerd. Toch is een beeld verkregen (Figuur 2.9A-E).

A

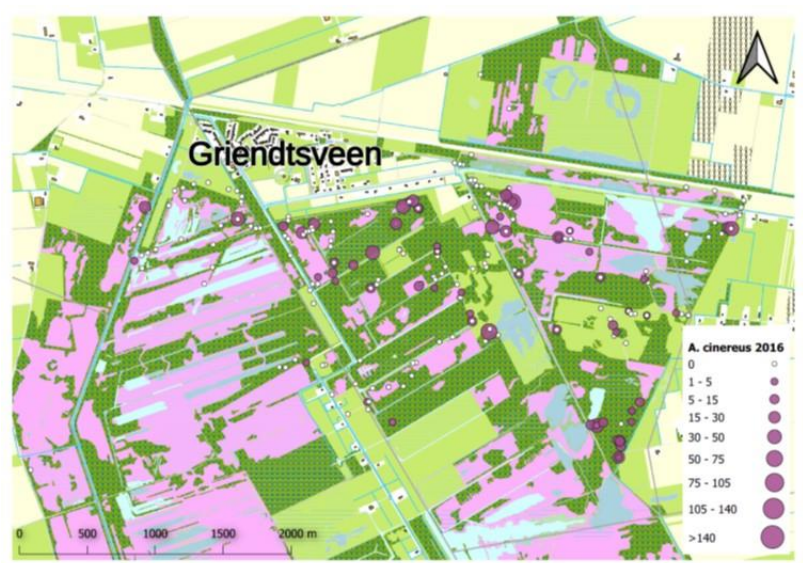

C

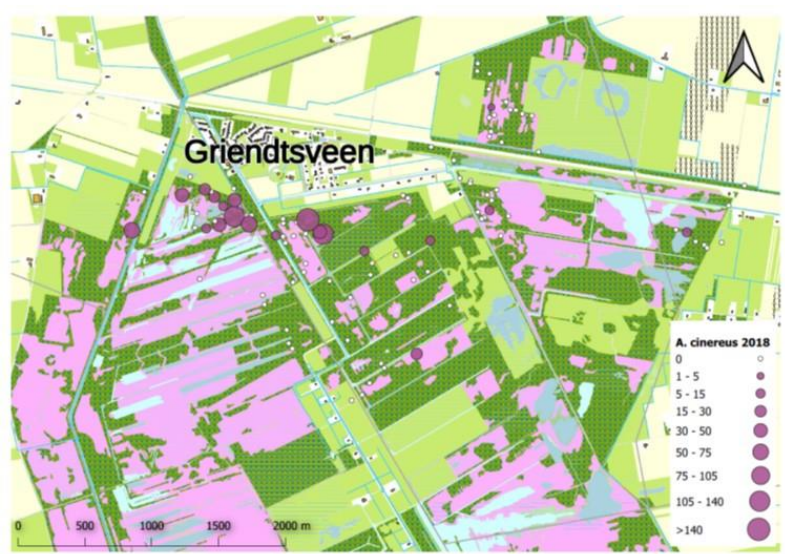

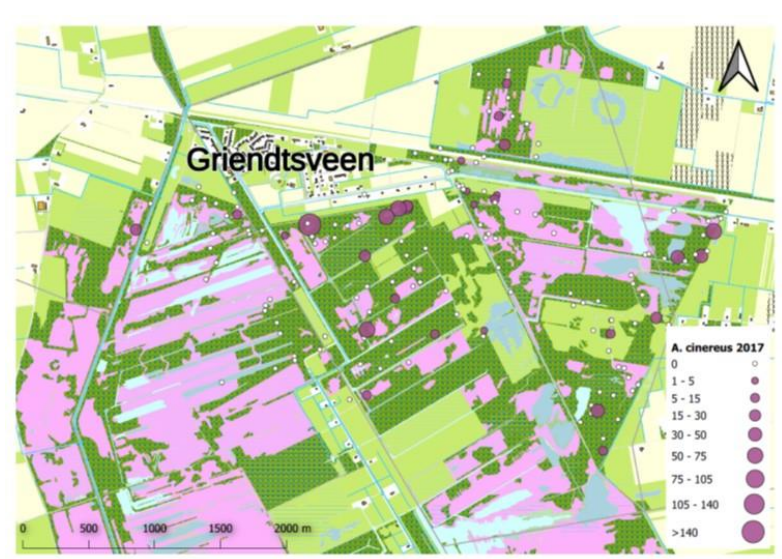

D

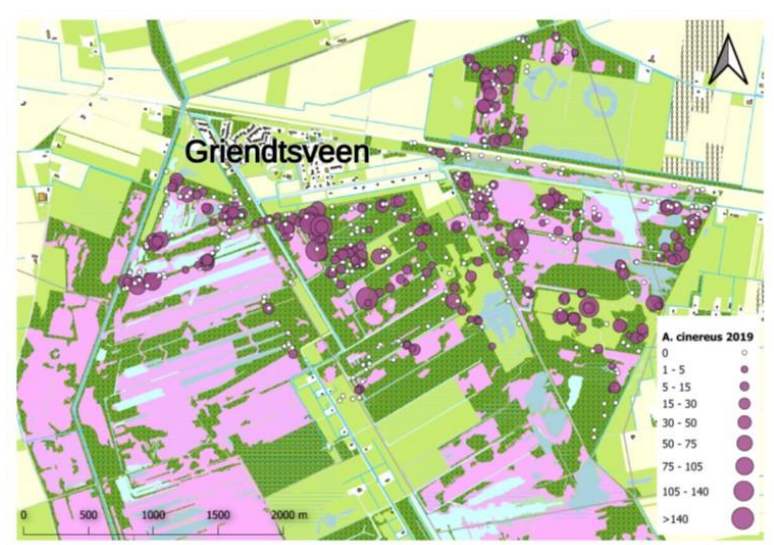




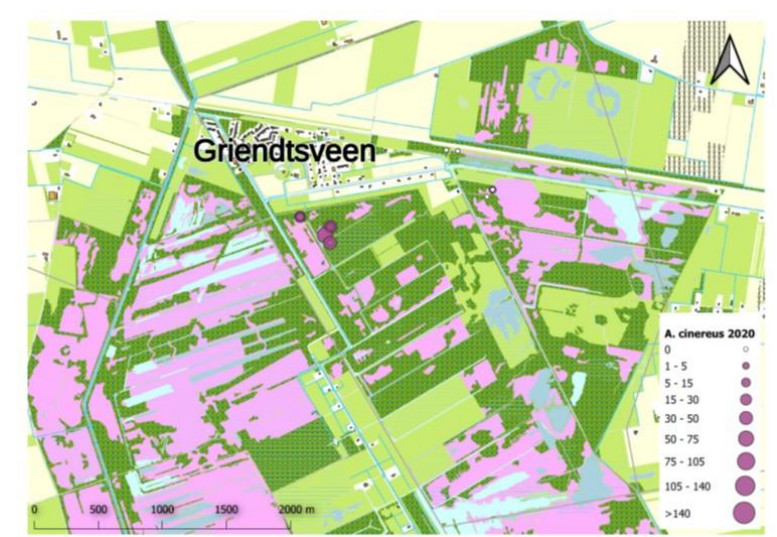

Figuur 2.9: De ruimtelijke verdeling van larvale broedplaatsen is in de jaren $2016(A), 2017$ (B), 2018 (C), 2019 (D), 2020 (E). De ogenschijnlijke verschillen duiden niet alleen op werkelijk verschillen maar ook op verschillen in ruimtelijke dekking van het aantal bemonsterde en herhaald bemonsterde plekken.

Het patroon in de verspreiding van larven laat een verspreid beeld zien van hogere aantallen over de onderzochte $2 \mathrm{~km}$ zone. Vooral de intensieve inventarisatie in 2019 bevestigt dit beeld. Naast de over het gebied verspreidde productie van veenmoerassteekmuggen blijft het zuidwestelijk compartiment dat aan het dorp grenst hoge aantallen produceren in meerdere jaren. De inventarisaties maken duidelijk dat er broedplaatsen lagen nabij de rand van het natuurgebied (voorheen de hotspots) maar dat er verspreid over de $2 \mathrm{~km}$ overal dergelijke plekken voorkwamen. Daarnaast blijft de $2 \mathrm{~km}$ zone een aanname op basis van de vliegcapaciteit van metingen $n$ een ander gebied.

Een opvallend detail is het lage aantal verzamelde volwassen dieren in 2019 t.o.v. het hoge aantal larven. De oorzaak is mogelijk een gevolg van de periode van bemonsteren die voor larven veel korter was dan voor volwassen dieren.

\subsection{De ecologie van de veenmoerassteekmug (A. cinereus)}

De ecologie van de veenmoerassteekmug ( $A$. cinereus) is uitgebreid beschreven in bijlage 1 . $A$. cinereus heeft een voorkeur voor tijdelijke wateren, vooral die wateren die tot ongeveer tot de helft van het jaar water bevatten, zogenaamde langdurig tijdelijke wateren. Voor de ei-afzetting hebben de volwassen dieren een voorkeur voor kleine zure wateren zoals poeltjes (minder dan $6 \mathrm{~m}^{2}$ en minder dan $40 \mathrm{~cm}$ diep), greppels en droogvallende wijken en sloten, in feite depressies in het landschap die tijdelijk water bevatten. In de periode april - mei bij een temperatuur van $5-13^{\circ} \mathrm{C}$ komen de eitjes uit ongeacht of ze daarvoor onder water liggen. Bij hogere temperaturen kan de larf in slechts 8-10 dagen opgroeien. De volwassen dieren verschijnen, afhankelijk van de temperatuur, vanaf april en kunnen verder de gehele zomer tot in het najaar worden aangetroffen. De helft van de populatie is vaak binnen 13 tot 19 dagen na aanvang van de emergentie uitgevlogen. De soort heeft daarmee een piek in aantallen in het voorjaar, eventueel gevolgd door een tweede piek na een natte periode in de nazomer. De actieradius van de volwassen dieren is ongeveer $1.5-2 \mathrm{~km}$.

De ecologie zoals hierboven beschreven sluit aan bij de waarnemingen in de verschillende jaren in het onderzoeksgebied (paragraaf 2.2). Wat betekent dat de waterhuishouding als gevolg van weersomstandigheden en gebiedskenmerken, incl. waterbeheer, invloed op de populatiegrootte kunnen hebben gehad.

\subsection{Knutten}

Tijdens het over zes jaren monitoren van knutten in de maanden april (in 2015 vanaf mei) tot en met september op (meestal) 18 locaties vallen twee ontwikkelingen op. Er trad een lineaire toename in aantallen volwassen knutten op van 2015 tot en met 2018 (Figuur 2.9). In 2019 vielen de aantallen terug naar bijna het niveau van 2015 met daaropvolgend een toename in 2020 naar de aantallen van 2017. Wat 
betreft de maand waarin de groep piekte was achtereenvolgens mei 2015, mei en juli 2016, mei-juni 2017, mei 2018, mei-juni 2019 en mei 2020. Mei lijkt dus een echte knuttenmaand.

De soorten verantwoordelijk voor de hoge aantallen waren achtereenvolgens Culicoides impunctatus (64\%), C. festivipennis gr. (13\%), C. punctatus (9\%), C. obsoletus gr. (4\%), C. kibunensis (3\%), C. pictipennis (3\%) en C. pallidicornis (2\%) (Figuur 2.10). De overige taxa namen ieder $1 \%$ of minder van het totaal aan individuen in. Indien naar mogelijke overlast door knutten wordt gekeken dan komt $C$. impunctatus als meest talrijk soort naar voren en zouden de andere soorten lokaal talrijker kunnen optreden.

Uit de verdeling over de maanden blijkt dat de soorten op verschillende momenten piekten; C. pictipennis in april, C. impunctatus in mei, C. punctatus, C. kibunensis en C. pallidicornis in juni, C. festivipennis gr. in juli en Culicoides obsoletus gr. in september (Tabel 2.3). Wat betreft mogelijk talrijk optreden zijn de soorten die op enig moment in mei-augustus pieken het belangrijkste. Overigens kunnen de piekmomenten tussen jaren enigszins verschillen door verschillende verlopen in temperatuur.

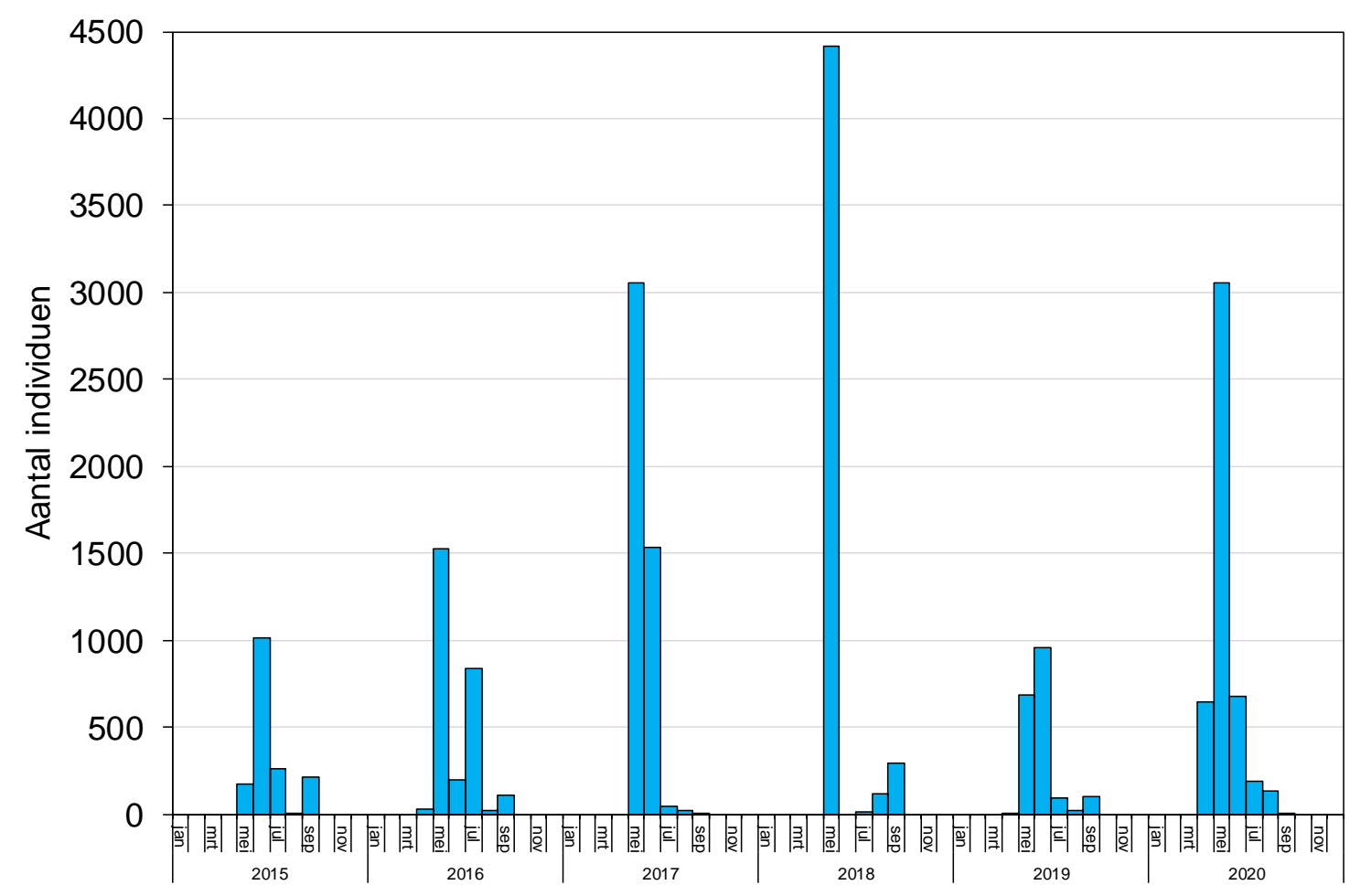

Figuur 2.9: Het aantal individuen van volwassen knutten per maand over de jaren 2015-2020. 


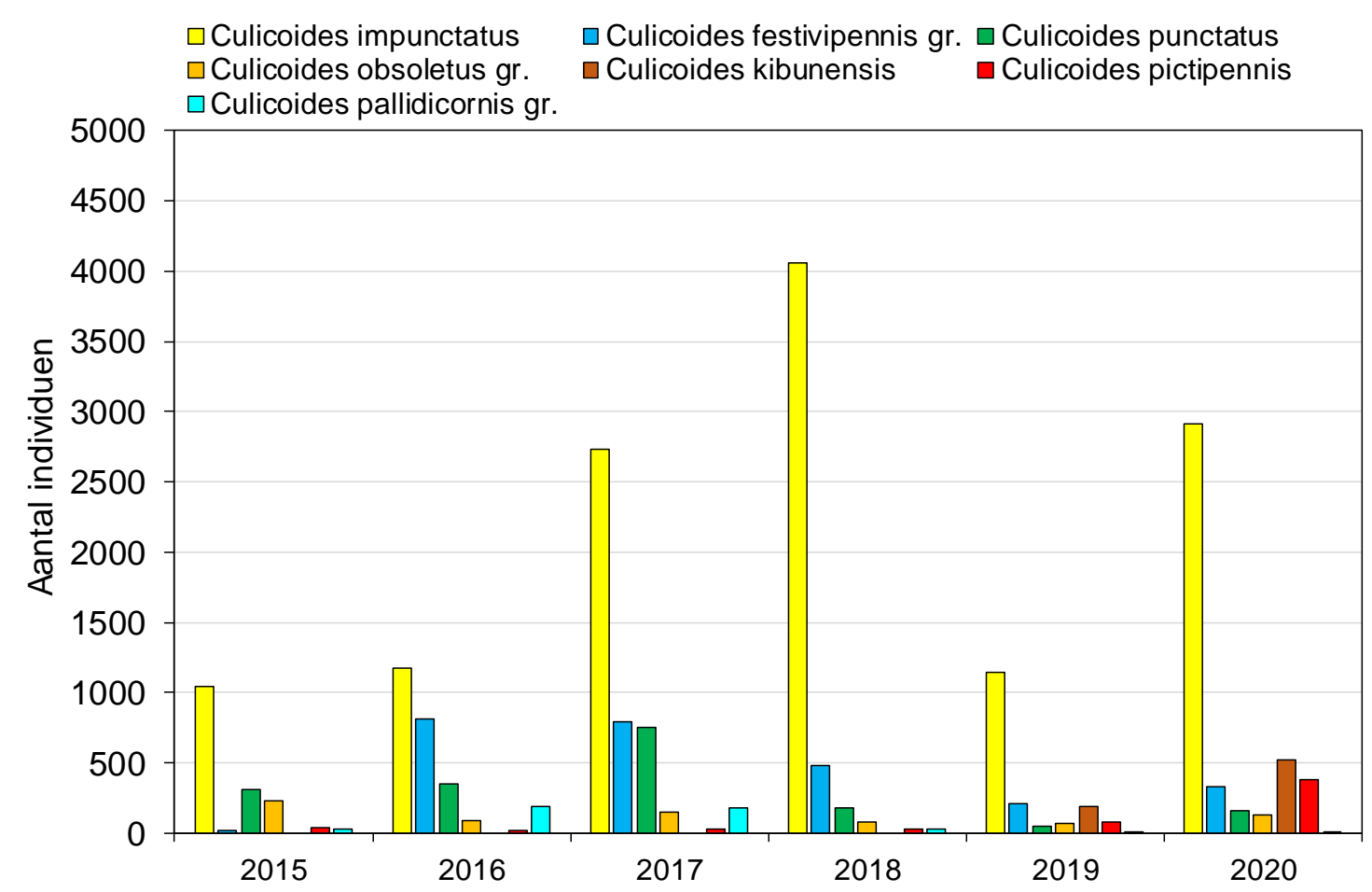

Figuur 2.10: Het aantal individuen van de vijf meest dominante soorten knutten over de jaren 20152020.

Tabel 2.3: Het gesommeerd over de periode 2015-2020 optreden van de soorten knutten per maand.

\begin{tabular}{|c|c|c|c|c|c|c|c|}
\hline & 效 & 童 & 岌 & 苞 & $\begin{array}{l}\text { D } \\
\text { c } \\
\text { c } \\
\text { n } \\
\text { c } \\
\text { n }\end{array}$ & 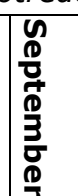 & 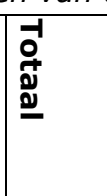 \\
\hline Culicoides impunctatus & 213 & 11003 & 1778 & 62 & 8 & 1 & 13065 \\
\hline Culicoides festivipennis gr. & 3 & 623 & 589 & 891 & 219 & 317 & 2642 \\
\hline Culicoides punctatus & 26 & 565 & 763 & 258 & 36 & 157 & 1805 \\
\hline Culicoides obsoletus gr. & 52 & 165 & 182 & 85 & 32 & 232 & 748 \\
\hline Culicoides kibunensis & 5 & 197 & 490 & 14 & 4 & & 710 \\
\hline Culicoides pictipennis & 368 & 190 & 17 & 7 & & & 582 \\
\hline Culicoides pallidicornis gr. & & 37 & 353 & 31 & 12 & 8 & 441 \\
\hline Culicoides minutissimus & & 20 & 131 & 68 & 6 & & 225 \\
\hline Culicoides & & 83 & 4 & & & & 87 \\
\hline Culicoides vexans & 2 & 1 & 29 & 25 & & & 57 \\
\hline Culicoides albicans & 3 & 21 & 9 & 1 & & & 34 \\
\hline Culicoides dewulfi & 3 & 3 & 3 & 3 & & 1 & 13 \\
\hline Culicoides segnis & & 1 & 9 & & & & 10 \\
\hline Culicoides sphagnumensis & & 1 & 5 & & 3 & & 9 \\
\hline Culicoides chiopterus & & & 2 & 1 & 5 & & 8 \\
\hline Culicoides circumscriptus & & 2 & 6 & & & & 8 \\
\hline Culicoides alazanicus & & & 4 & 2 & & & 6 \\
\hline Culicoides heliophilus & & 2 & 1 & & & & 3 \\
\hline
\end{tabular}




\begin{tabular}{|c|c|c|c|c|c|c|c|}
\hline & $\begin{array}{l}\text { D } \\
\text { D. } \\
\text { ב. }\end{array}$ & $\begin{array}{l}\mathbf{3} \\
\mathbf{Q}\end{array}$ & 岌. & 鴶 & 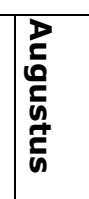 & 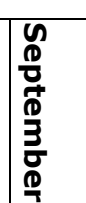 & 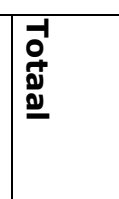 \\
\hline Culicoides salinarius & & 1 & & 1 & & 1 & 3 \\
\hline Culicoides scoticus & 2 & & & & & & 2 \\
\hline Culicoides achrayi & & & 1 & & & & 1 \\
\hline Culicoides duddingstoni & & & 1 & & & & 1 \\
\hline Culicoides fascipennis & & & & 1 & & & 1 \\
\hline Totaal & 677 & 12915 & 4377 & 1450 & 325 & 717 & 20461 \\
\hline
\end{tabular}

De ruimtelijke verdeling van de hogere aantallen, met name taxa die gesommeerd over de jaren met meer dan 500 individuen verzameld zijn, betreft $C$. impuntatus, $C$. punctatus en $C$. festivipennis gr. alle aan de rand van het natuurgebied (7 locaties), een locatie in het dorp (GR09), twee locaties aan de westrand (GR12, GR13) en een aan de oostrand (GR06) (Figuur 2.11). De locatie in het dorp ligt naast een sloot. De sloot of slootoever kan lokaal hogere aantallen geven.

De ruimtelijke verdeling van de aantallen individuen van knutten over de 18 locaties laat zien dat er, behalve in 2015, jaarlijks pieken voorkwamen op GR12 en GR13 in 2016, op GR02, GR07, GR11 en GR14 in 2017, op GR06 en GR11 in 2018 en op GR01 en GR16 in 2020. Dit betekent dat alleen op locatie GR11 tweemaal in de zes meetjaren er meer dan 500 individuen waren verzameld op dezelfde plek.

De wisselingen in aantallen over de jaren, de spreiding over de maanden en taxa en de wisselende ruimtelijke verdeling geven aan dat bij de knutten sprake is van lokaal talrijk optredende populaties van verschillende taxa (soorten en soortgroepen) op verschillende momenten in de tijd. Hierbij liggen de hogere aantallen wel vaak aan de rand van het natuurgebied (Figuur 2.12).

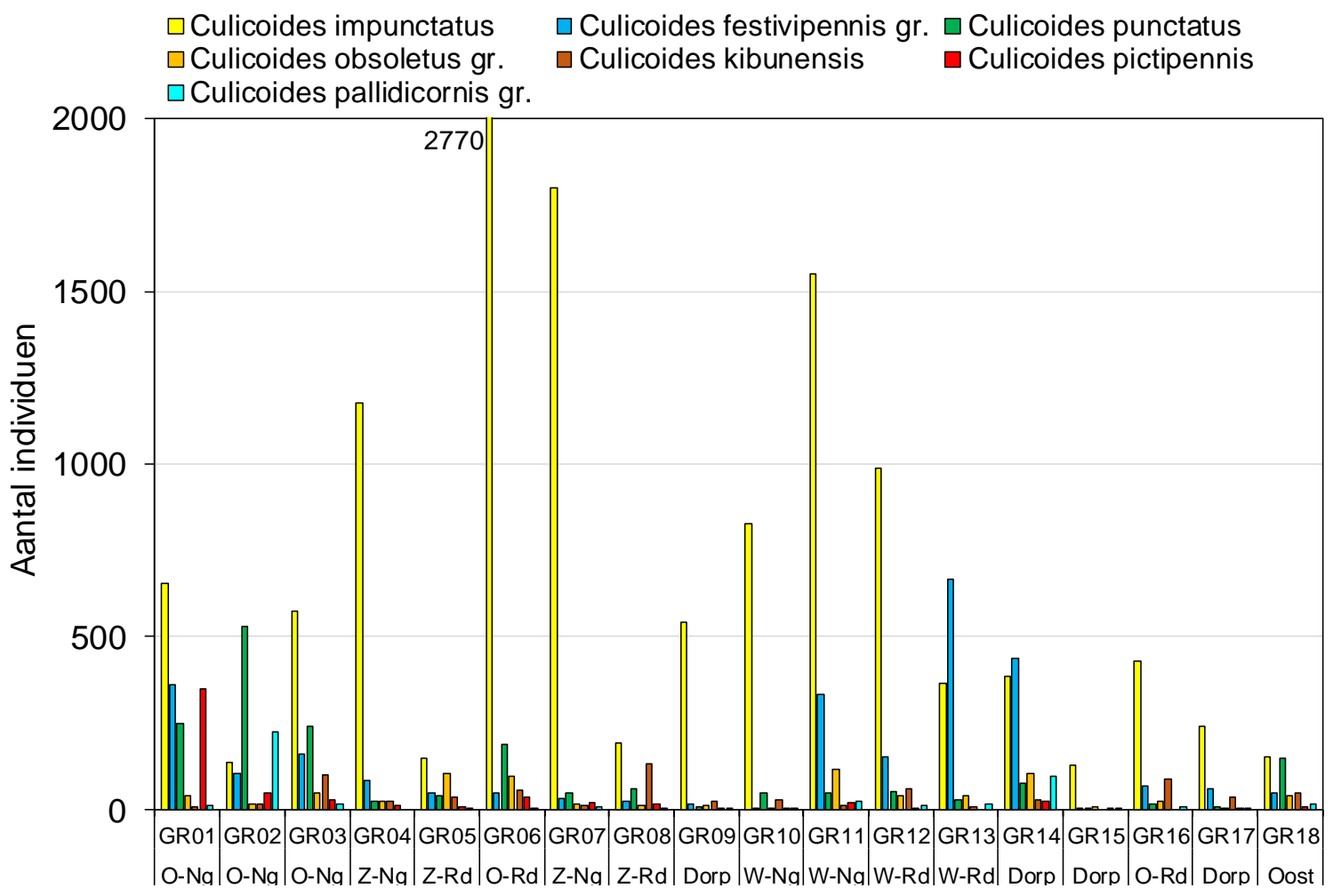

Figuur 2.11: De verdeling van de gesommeerde aantallen individuen over de periode 2015-2020 van de zeven meest talrijk voorkomende soorten knutten over de 18 monsterlocaties. 


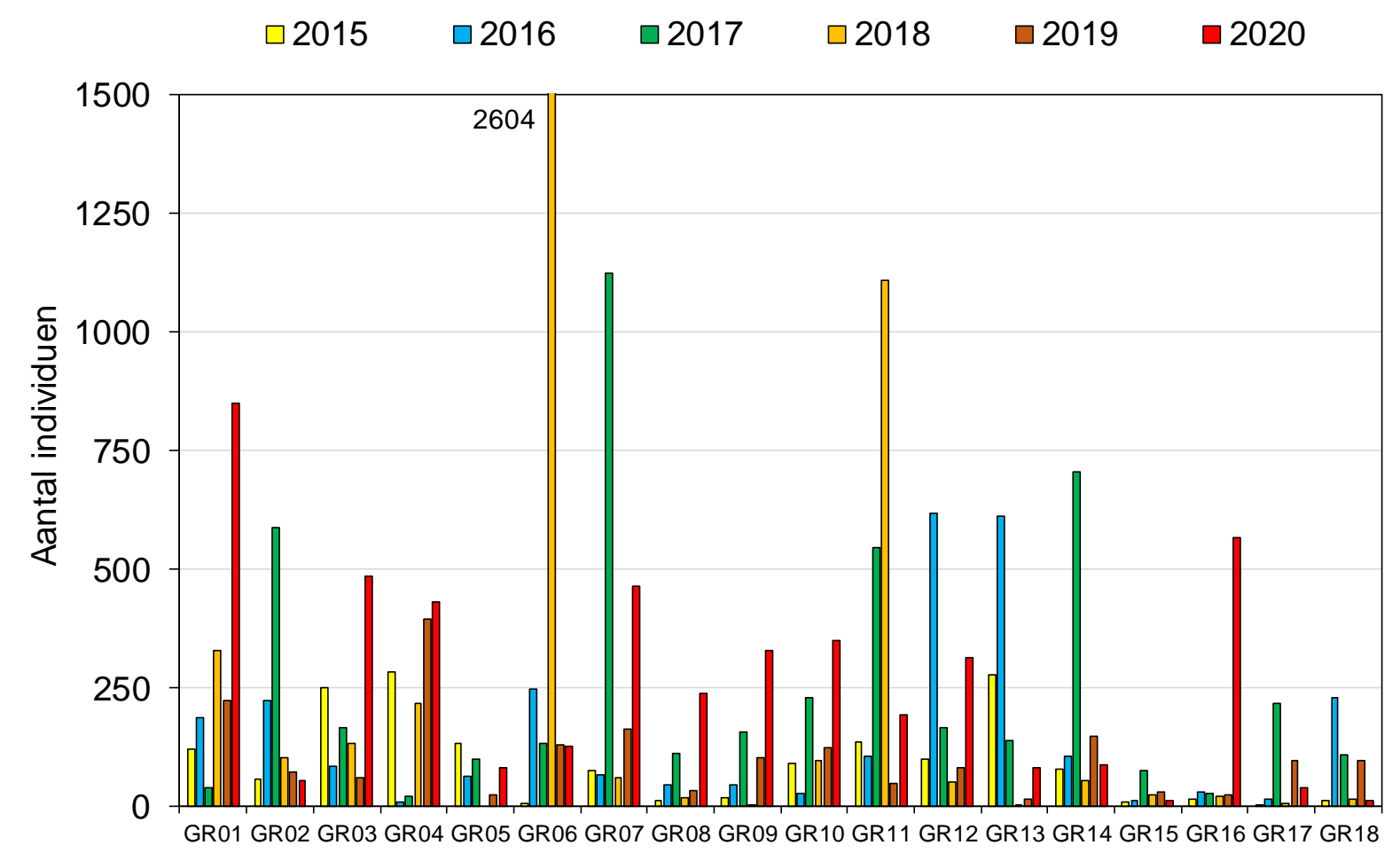

Figuur 2.12: De verdeling van de gesommeerde aantallen individuen over de periode 2015-2020 van soorten knutten over de 18 monsterlocaties.

\subsection{De habitat van de belangrijkste knutten}

De ecologie van de knutten is uitgebreid beschreven in bijlage 2. Een korte omschrijving staat hieronder. Culicoides impunctatus is een typische soort van voedselarmere, drassige, zure bodems in (veen)moerassen en de overgangszones tussen moeras en drogere omgeving. De soort gedijt in minder voedselrijke vochtig tot natte bodems. De soort treedt vooral op in mei met een tweede piek in september maar kan van het voor- tot in het najaar worden aangetroffen. De soort bijt niet specifiek de mens, vooral vee.

Culicoides festivipennis gr. heeft een voorkeur voor poelen met veel emergente planten (o.a. lisdodde (Typha), russen (Juncus), zegges (Carex)) in de oevers en verlandingszones, maar kan ook voorkomen in bijna alle natte organische milieus, drassige organische gronden, weinig begroeide, slibrijke bospoelen en dergelijke. De soort heeft 4-5 generaties per jaar en bijt vogels.

Culicoides punctatus leeft in natte graslanden waar vee weidt en mest aanwezig is en leeft ook tussen emergente vegetaties (o.a. lisdodde (Typha), russen (Juncus), zegges (Carex)) in de oevers van poelen, in organische moerassen en vochtige. De soort bijt vogels en zoogdieren.

Culicoides obsoletus gr. leeft in allerlei milieus van organisch verrijkte bodems op beschaduwde plaatsen, veenbodems en, bij voorkeur, met mest doorwerkte agrarische gronden. De soort bijt zoogdieren en vogels.

Culicoides kibunensis is een soort van modderige bosgrond en weinig begroeide, slibrijke bospoelen. De soort bijt vogels.

Culicoides pictipennis ontwikkelt zich nabij boerderijen en in de oeverzones van poelen, vooral drinkpoelen. Het is een typische voorjaarssoort. De soort bijt vooral vogels. 
Culicoides pallidicornis is een algemene, wijdverspreide soort die zich vooral ontwikkelt in rottend blad onder houtige begroeiingen. De soort bijt zoogdieren.

Op basis van de ecologie van de verschillende soorten knutten blijkt dat de meest talrijke soort $C$. impunctatus uit het natuurgebied afkomstig is. De tweede talrijkste soort, C. festivipennis gr., en de iets minder talrijke soorten $C$. kibunensis en $C$. pictipennis, bijten alleen vogels en zijn niet relevant in dit onderzoek. De soorten C. punctatus, C. obsoletus gr. en C. pallidicornis leven in slootoevers, natte weilanden en andere agrarische/urbane plekken in en rondom het dorp maar kunnen ook in het natuurgebied opgroeien.

\subsection{Weers-en gebiedsomstandigheden}

De waterhuishoudkundige situatie in het onderzoeksgebied is een belangrijke sleutelfactor voor het optreden van overlast. Hierbij spelen drie factoren een rol: de temperatuur, de neerslag en de grondwaterstanden. Samen zijn deze factoren bij de slecht doorlatende veengrond verantwoordelijk voor het optreden van verschillende typen oppervlaktewateren zoals langdurig tijdelijke wateren.

\section{Temperatuur}

Het temperatuurverloop over de jaren 2015-2020 is cumulatief berekend, wat betekent dat de gemiddelde dagtemperatuur steeds is opgeteld bij de vorige dag (vanaf 1 januari van het betreffende jaar en met alleen temperaturen $>0^{\circ} \mathrm{C}$ ) zodat een toename in totale warmte (energie) zichtbaar wordt. Deze benadering is gekozen omdat de ontwikkeling van stekende insecten direct samenhangt met de opwarming in graaddagen (in theorie zou de temperatuur waarop de eitjes beginnen te ontwikkelen moeten worden gekozen maar die informatie is onbekend). De periode 1985-2014 is genomen als 30-jarige referentieperiode.

Het cumulatieve verloop van de luchttemperatuur laat zien dat alle jaren behalve de eerste 10 maanden van 2015 boven het 30-jarig gemiddelde liggen (zwarte lijn in Figuur 2.13). De jaren 2018 en 2020 waren daarvan het warmst. De temperatuur is voor de veenmoerassteekmug ( $A$. cinereus) vooral van belang in het voorjaar wanneer de eitjes uitkomen en de larven gaan groeien. Daarom is in figuur 2.13 ingezoomd op de eerste vijf maanden (Figuur 2.14). Opvallend is dat 2016, 2018 en 2020 een warme start kenden terwijl 2017 juist koeler was. Dit patroon veranderde in maart waarna het juist in 2019 en 2020 warmer bleven t.o.v. de andere getoonde jaren en het langjarig gemiddelde. Vanaf mei werd het in 2018 steeds warmer en benaderde de temperatuur de 2020 lijn. Juist deze latere periode tussen maart en mei is gunstig voor de ontwikkeling van de veenmoerassteekmug ( $A$. cinereus). 


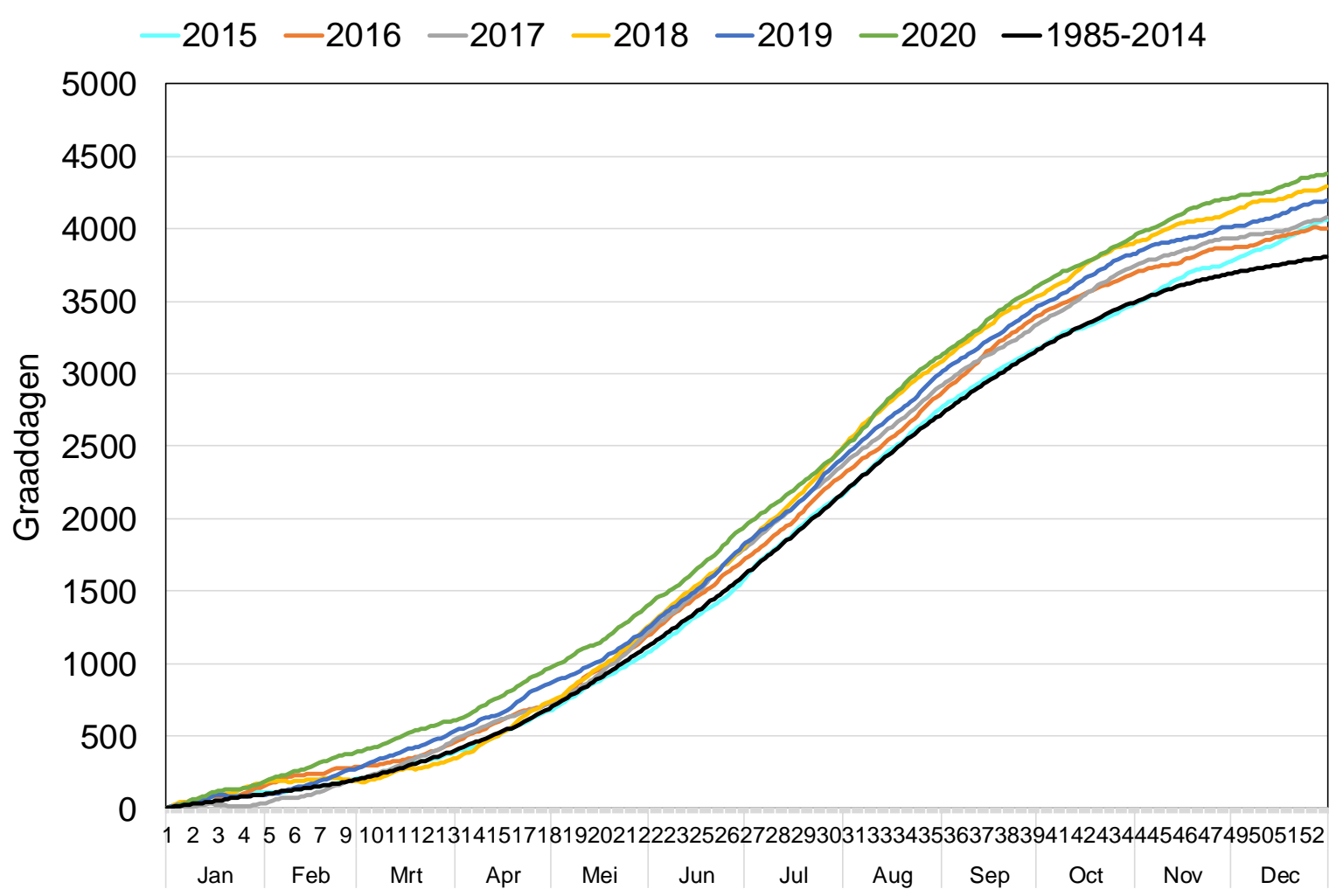

Figuur 2.13: Het cumulatieve verloop van de luchttemperatuur in graaddagen over het jaar gemeten op weerstation Eindhoven over de periode 2015-2020. Bron: http://www.knmi.nl/nederlandnu/klimatologie/daggegevens.

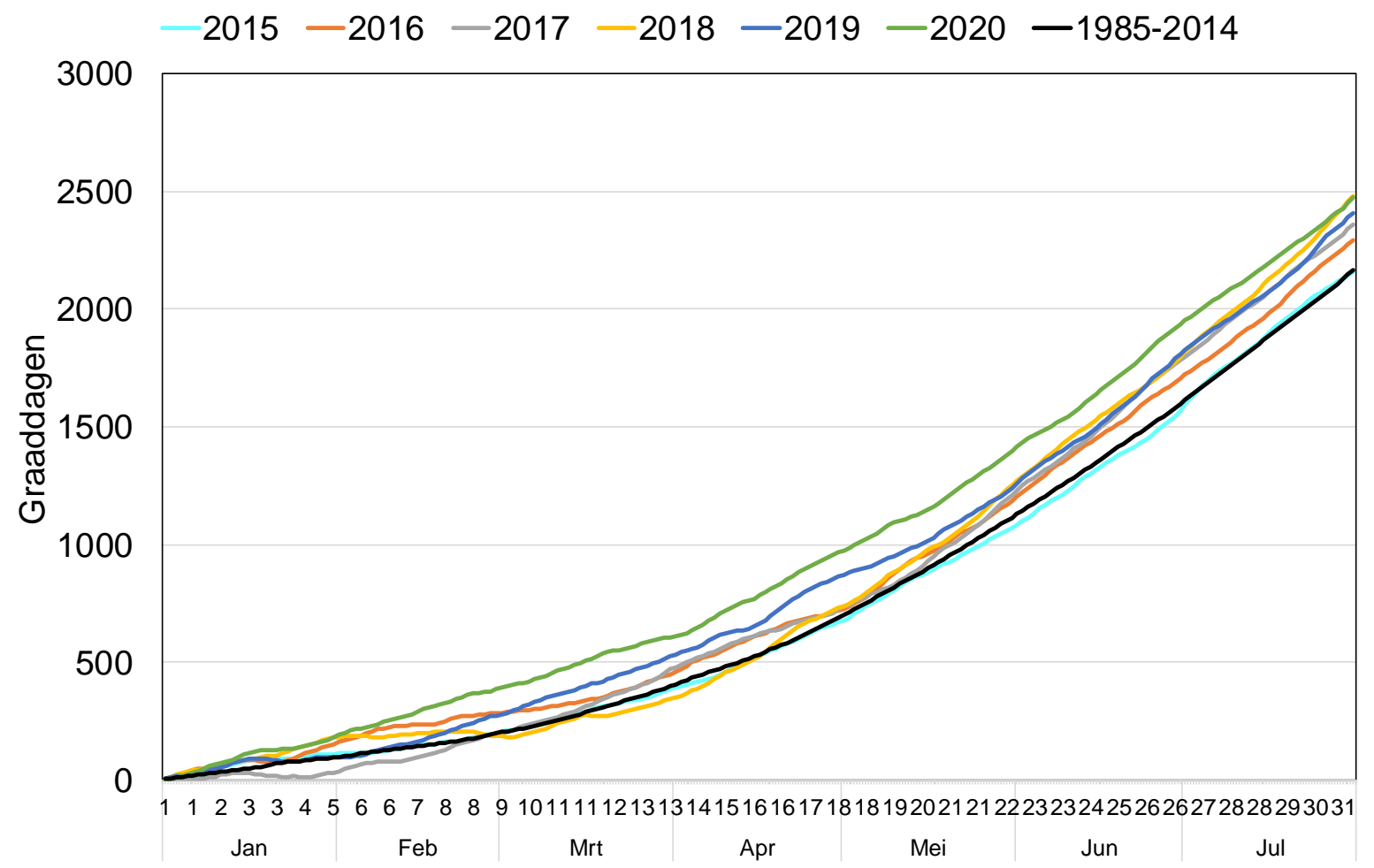

Figuur 2.14: Het cumulatieve verloop van de luchttemperatuur in graaddagen over de maanden januarijuli gemeten op weerstation Eindhoven over de periode 2015-2020. Bron: http://www.knmi.nl/nederlandnu/klimatologie/daggegevens. 


\section{Neerslag}

Het neerslagoverschot (bruto neerslag min referentieverdamping) laat zien dat in 2015 de maanden apriljuli een neerslagtekort hadden terwijl dat opliep naar de maanden april-september in 2019 en 2020 (Figuur 2.16). Met een droge maand februari was 2018 ook al een extreem droog jaar. In juni 2016 en februari 2020 traden zeer natte perioden op, voor de veenmoerassteekmug is het laatste van belang.

Het neerslagoverschot was het hoogst in $2016(206 \mathrm{~mm})$ en het laagst in $2018(-80 \mathrm{~mm})$. De andere jaren wisselde de cijfers (2015 44 mm, $201791 \mathrm{~mm}, 201948 \mathrm{~mm}$ en $2020-8 \mathrm{~mm}$ ) terwijl voor het neerslagoverschot $250-300 \mathrm{~mm}$ wordt aangehouden. De metingen hebben dus in droge tot zeer droge jaren plaatsgevonden.

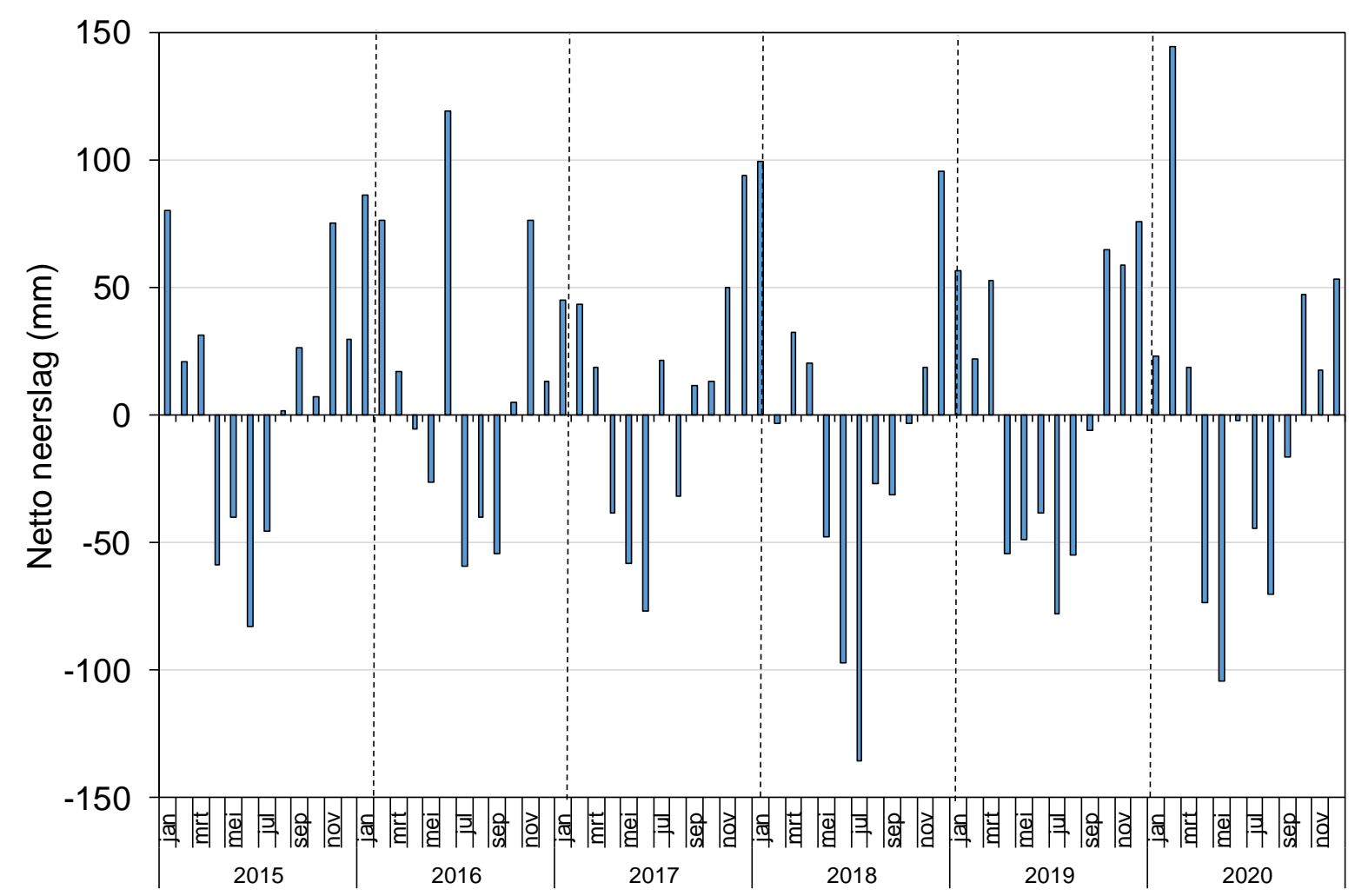

Figuur 2.16: De maandelijkse netto neerslag op station Eindhoven in de periode 2015-2020. Bron: KNMI: http://www.knmi.nl/nederland-nu/klimatologie/daggegevens.

Om te bepalen hoeveel de weersomstandigheden bij hebben gedragen aan de verklaring van de populatieontwikkeling van de veenmoerassteekmuggen is een multiple regressie (een regressie waarbij meerdere verklarende variabelen de te verklaren variabele (hier de populatie-opbouw) verklaren) uitgevoerd. Hierbij zijn de volgende parameters en aannames gebruikt:

- De aantallen van de veenmoerassteekmug zijn gelogaritmiseerd om een lineair toename te simuleren.

- Alle vangsten vooraf en op het moment van het maximale aantal zijn in de analyse meegenomen om zo de opbouw van de maximale populatiegrootte en daarmee het moment van potentiële overlast te bepalen.

- De temperatuursom is de som van de daggemiddelde temperatuur over een $x$ aantal dagen vooraf de datum van monstername. De temperatuursom is berekend voor respectievelijk 7, 14, 28, 42, $56,70,84,98,112,126,140,154,168$ en 182 dagen vooraf aan de monstername.

- De som van de netto neerslag is de som van de dagwaarde van de neerslag min de verdamping over een $\mathrm{x}$ aantal dagen vooraf de datum van monstername. De netto neerslagsom is berekend voor respectievelijk 7, 14, 28, 42, 56, 70, 84, 98, 112, 126, 140, 154, 168 en 182 dagen vooraf aan de monstername. 
De multiple stapsgewijze regressie leverde een best verklarend model waarbij de geselecteerde variabelen significant zijn $\left(F=20.9 P<0.001\right.$ ) samen $71 \%$ (Adjusted $R^{2}$ ) van de variatie verklaarden (Tabel 2.4). De regressiecoëfficiënten van T56 e NN42 zijn 0.007 en -0.001 en significant (t (T56) $=5.504 ; p<.001 ; t$ $(\mathrm{NN} 42)=-2.745 ; \mathrm{p}=.016)$.

Tabel 2.4: Resultaten van de stapsgewijze multiple regressie met de gelogaritmiseerde aantallen individuen van de opbouwende populatie van de veenmoerassteekmug als afhankelijk variabele en de temperatuursom en de som van de netto neerslag over de periode van respectievelijk $7,14,28,42,56$, $70,84,98,112,126,140,154,168$ en 182 dagen vooraf aan de monstername als verklarende variabelen.

\begin{tabular}{|c|c|c|c|c|c|c|c|c|}
\hline \multicolumn{9}{|c|}{ Model Summary } \\
\hline \multirow{3}{*}{$\begin{array}{l}\text { Model } \\
3\end{array}$} & \multicolumn{8}{|c|}{ Durbin-Watson } \\
\hline & $\mathrm{R}$ & $\mathrm{R}^{2}$ & Adjusted $\mathrm{R}^{2}$ & RMSE & \multicolumn{2}{|c|}{ Autocorrelation } & Statistic & $\mathrm{p}$ \\
\hline & 0.866 & 0.749 & 0.713 & 0.837 & \multicolumn{2}{|l|}{0.127} & 1.708 & 0.507 \\
\hline \multicolumn{9}{|c|}{ ANOVA } \\
\hline Model & \multicolumn{3}{|c|}{ Sum of Squares } & $\mathrm{df}$ & $\begin{array}{l}\text { Mean } \\
\text { Square }\end{array}$ & $F$ & $\mathrm{p}$ & \\
\hline \multirow[t]{3}{*}{3} & Regression & \multicolumn{2}{|c|}{29.327} & 2 & 14.664 & 20.916 & $<.001$ & \\
\hline & \multicolumn{2}{|l|}{ Residual } & 9.815 & 14 & \multicolumn{2}{|l|}{0.701} & & \\
\hline & Total & \multicolumn{2}{|c|}{39.142} & 16 & & & & \\
\hline
\end{tabular}

Coefficients

\begin{tabular}{|c|c|c|c|c|c|c|c|c|}
\hline \multirow[b]{2}{*}{ Model } & & & & & & & \multicolumn{2}{|c|}{ Collinearity Statistic } \\
\hline & & $\begin{array}{l}\text { Unstan- } \\
\text { dardized }\end{array}$ & $\begin{array}{l}\text { Standard } \\
\text { Error }\end{array}$ & $\begin{array}{l}\text { Standar- } \\
\text { dized }\end{array}$ & $\mathrm{t}$ & $\mathrm{p}$ & Tolerance & VIF \\
\hline 3 & (Intercept) & -2.595 & 0.801 & & -3.240 & 0.006 & & \\
\hline & T56 & 0.007 & 0.001 & 0.741 & 5.504 & $<.001$ & 0.987 & 1.013 \\
\hline & NN42 & -0.001 & $4.011 e-4$ & -0.370 & -2.745 & 0.016 & 0.987 & 1.013 \\
\hline
\end{tabular}

Note. The following covariates were considered but not included: T7, T14, T28, T42, T70, T84, T98, T112, T126, T140, T154, T168, T182, NN7, NN14 NN28, NN56, NN70, NN84, NN98, NN112, NN126, NN140, NN154, NN168 en NN182

Collinearity Diagnostics

\begin{tabular}{lllllll}
\hline & & & & & \\
\cline { 5 - 6 } Model & Dimension & Eigenvalue & $\begin{array}{l}\text { Condition } \\
\text { Index }\end{array}$ & (Intercept) & T56 & NN42 \\
\hline 3 & 1 & 2.413 & 1.000 & 0.010 & 0.010 & 0.068 \\
& 2 & 0.554 & 2.086 & 0.014 & 0.013 & 0.932 \\
& 3 & 0.033 & 8.580 & 0.976 & 0.977 & 0.001 \\
\hline
\end{tabular}

Uit de resultaten mag geconcludeerd worden dat vooral de oplopende temperatuursom in de circa twee maanden vooraf de maximale omvang van de populatie in combinatie met het oplopend neerslagtekort over de laatste anderhalve maand vooraf de maximale omvang van de populatie voor ruim $70 \%$ de talrijkheid bepaald. In andere worden, de weersomstandigheden hebben een grote, maar niet alle, invloed op de mate van ontwikkeling van veenmoerassteekmuggen.

\section{Grondwater}

De derde component die een belangrijke rol in de ontwikkeling van stekende insecten speelt is de waterhuishouding van het gebied. Door de maatregelen veranderde tijdens de maatregelfase de grondwaterstand in het natuurgebied.

Dit is zichtbaar gemaakt door het peilbuisverloop (verkregen van https://www.grondwatertools.nl/grondwatertools-viewer) op vijf locaties rondom het dorp Griendtsveen aan de rand van het natuurgebied weer te geven (Figuur 2.16A-F). De meest oostelijke locatie (Kanaalbos) laat een lichte daling van het grondwaterpeil zien, modelberekeningen gaven aan dat $90 \%$ van het patroon verklaard wordt uit neerslag en verdamping. De zuidoostelijke en zuidwestelijke locaties (Figuur 2.16B en 2.16D) laten een vrij sterke stijging in het grondwaterpeil zien, echter de stijging van de zuidoostelijke peilbuis is een gevolg van een filterverwisseling (Figuur 2.16C; med. C. Coenen). In de meetreeks van de zuidwestelijke peilbuis is mogelijk sprake van extreme drift van een diver. De grondwaterstand kan op die 
locatie geen 2 m zijn gestegen tot ca. 31.8 mNAP omdat het maaiveld hier op 31.08 mNAP ligt. M.a.w. dan zou het water $72 \mathrm{~cm}$ boven maaiveld staan. Mogelijk zijn de metingen in het najaar van 2017 gedaan tijdens droogval van het filter (een horizontaal verloop van de lijn). Dat de metingen toch enigszins oplopen kan eveneens wijzen op drift van de meetsensor (med. D. Coenen).

De westelijke locatie en een locatie aan de zuidzijde dieper in het gebied laten een constant patroon in het grondwaterpeil over de jaren zien (Figuur 2.16D en E). Dieper zuidelijk in het gebied liggen enkele grondwaterpeil meetbuizen waarvan tussen de $18-40 \%$ van de standen niet verklaard kan worden door neerslag en verdamping. In het Kanaalbos meer naar het oosten wordt circa $15-20 \%$ en aan de zuidwest zijde tussen de $12-36 \%$ niet verklaard door neerslag en verdamping. Concluderend: ook de gebiedsomstandigheden hebben ieder geval enige invloed op de waterhuishouding.

A

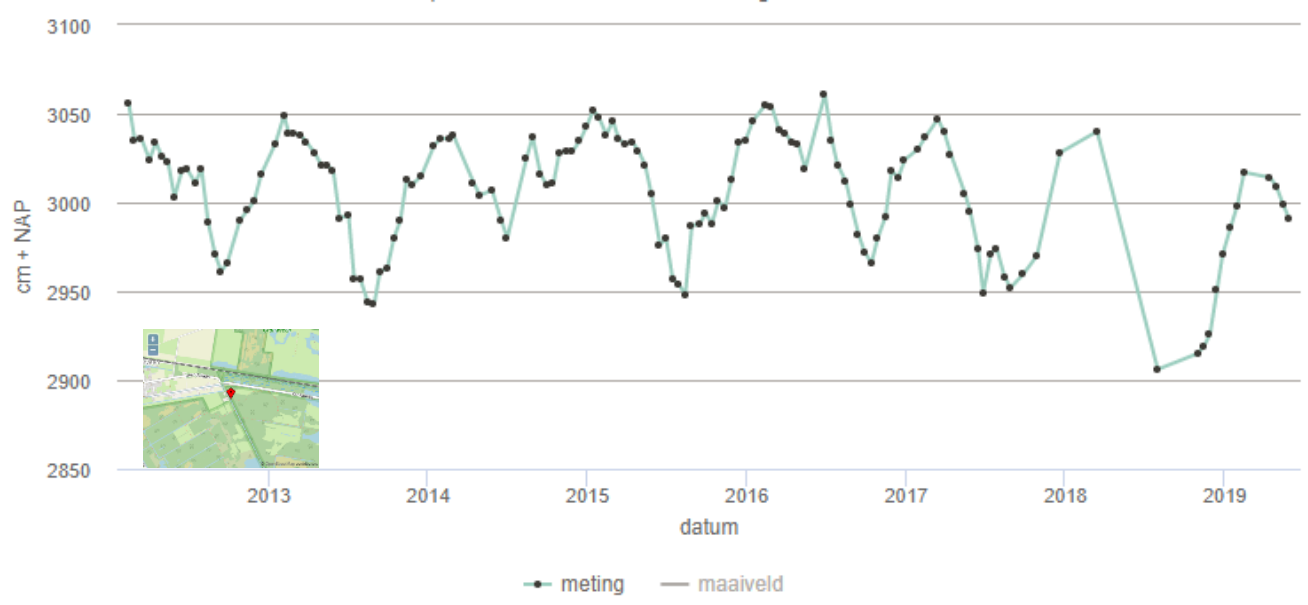

B

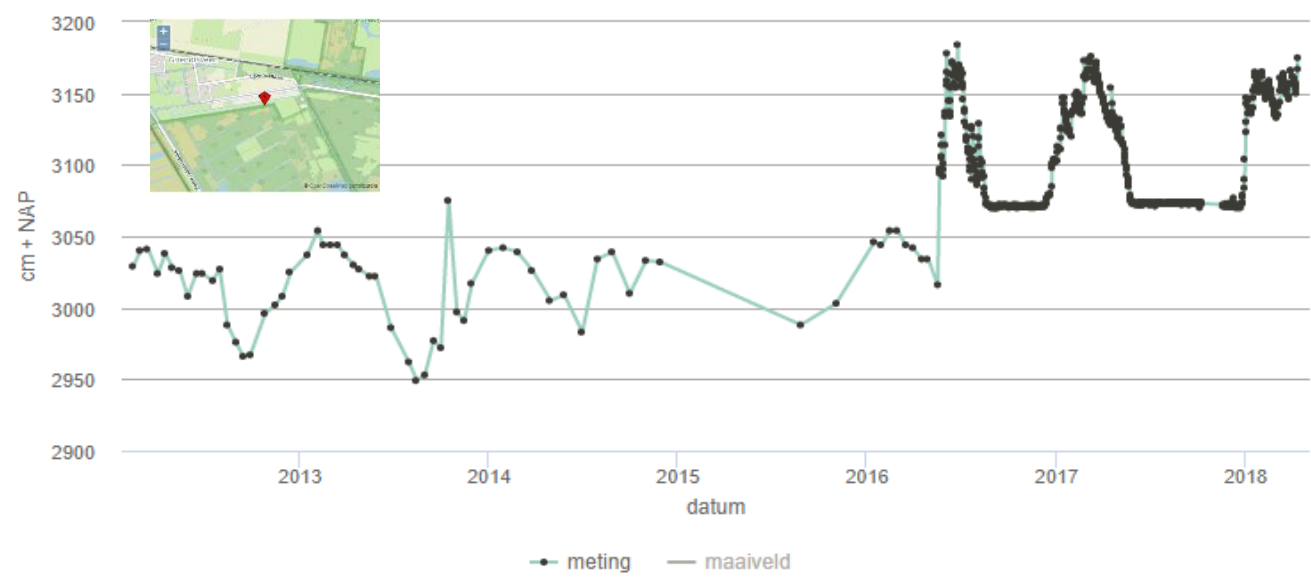


C

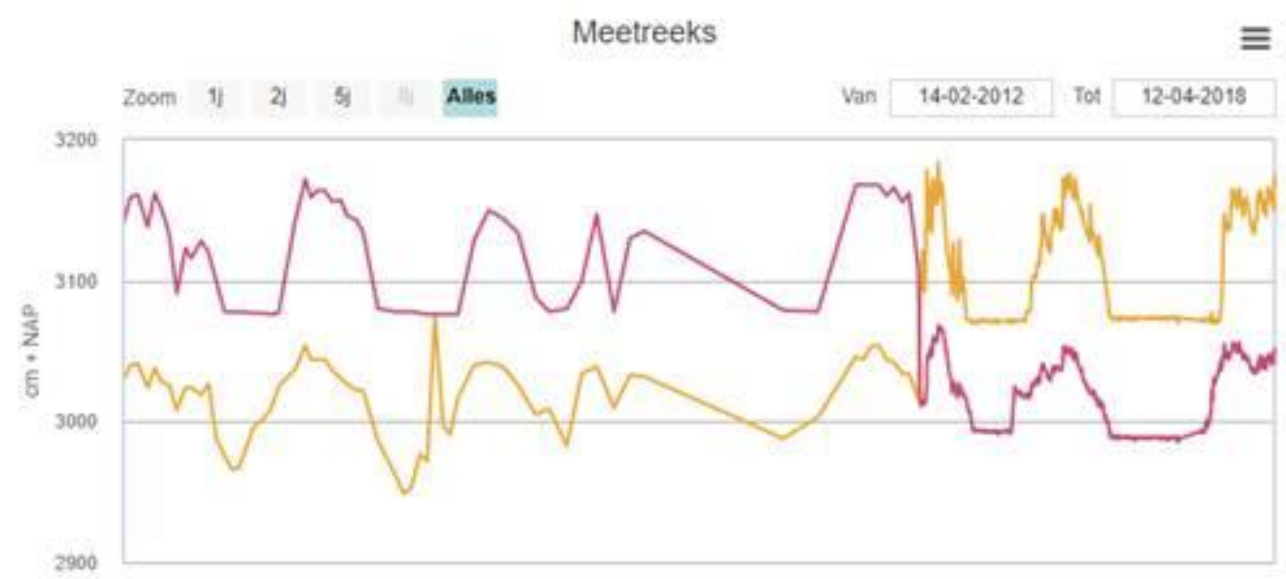

D

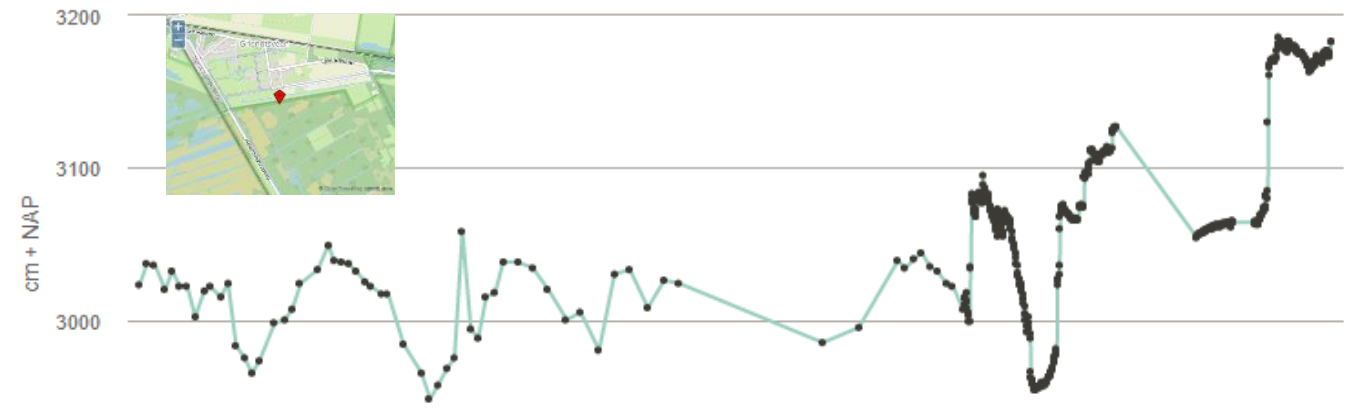

$\begin{array}{lccccc}2900 & 2013 & 2015 & 2016 & 2017 & 2018 \\ & & \text { datum } & & \end{array}$

E

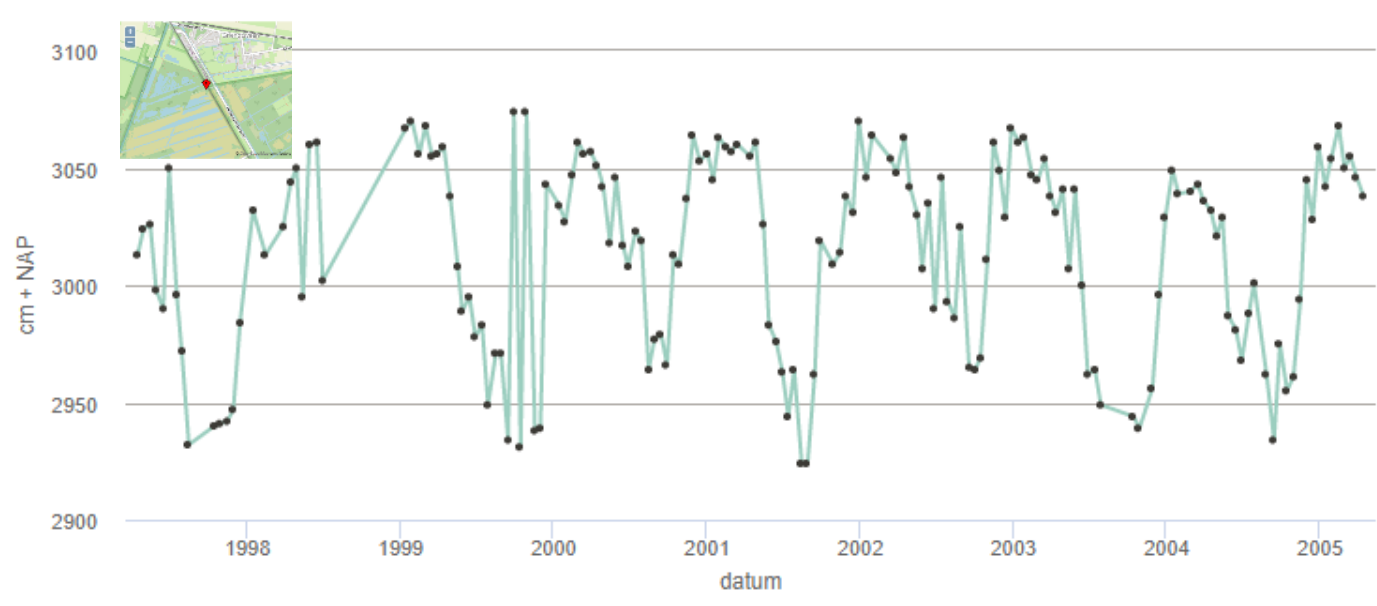

-- meting — maaiveld 


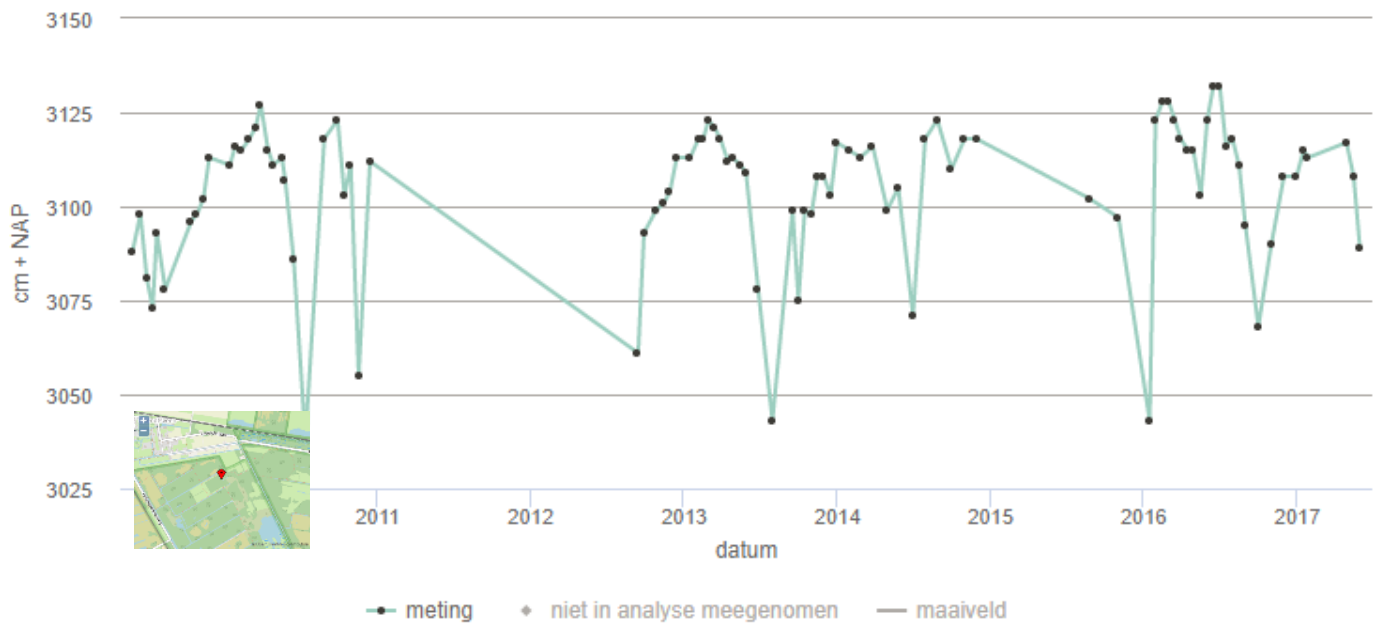

Figuur 2.16: Het verloop in het grondwaterpeil voor 5 locaties in het natuurgebied. A: locatie oost Horsterdriehoek, B: locatie zuidoost Driehonderd Bunders, C: Het omgewisselde verloop van de grondwaterstand op locatie zuidoost Driehonderd Bunders, D: locatie zuidwest Driehonderd Bunders, E: locatie zuidwest Deurnsche Peel naast Helenavaart, F: Deurnsche Peel westelijker. Bron: https://www.grondwatertools.nl/grondwatertools-viewer 


\section{Overlast in het natuurgebied en in het dorp}

\subsection{Ontstaan van overlast}

Om de vraag te kunnen beantwoorden 'Wanneer is sprake van overlast in het natuurgebied en in het dorp?' is het belangrijk eerst overlast te omschrijven. Er zijn enkele voorwaarden om overlast te doen ontstaan: een gunstig leefmilieu voor de steekmug, een geringe dichtheid van parasieten en predatoren, een voldoende voedselaanbod en een bepaalde omvang van de aanvangspopulatie.

\section{Gunstig leefmilieu}

Naar schatting kunnen circa 30 miljoen eitjes per $1000 \mathrm{~m}^{2}$ moeras worden afgezet en er bestaan waarnemingen van larvale dichtheden tot 50.000 per $\mathrm{m}^{2}$. In de larven inventarisaties zaten 10-20 larven per dip (diameter $12 \mathrm{~cm}$ ), wat een aantal van 88.000 tot 170.000 individuen per $100 \mathrm{~m}^{2}$ wateroppervlak betekent. Een landschap met poeltjes omvat conservatief geschat $25 \%$ water, dan kunnen daar nog steeds 22.000 tot 44.000 individuen voorkomen. Dat wil niet zeggen dat al deze larven tot volwassenheid ontwikkelen. Factoren, ook wel risicofactoren genoemd, zijn (met tussen haakjes het voor moerassteekmuggen positieve effect) droogval (aanwezig), waterbeweging/stroming (afwezig), terreinreliëf (aanwezigen onregelmatig), verlanding (sterk), temperatuur (hoog), milieudynamiek/extreme condities (aanwezig en sterk), inundaties (aanwezig), eutrofiëring/saprobiëring (aanwezig en verhoogd), struik-/boomopslag (aanwezig) en beheer (aanwezig)(o.a. Verdonschot 2009).

\section{Geringe dichtheid van parasieten en predatoren}

Moerassteekmuggen ontwikkelen zich meestal in tijdelijke wateren met een grote dynamiek in milieuvariabelen, zoals temperatuurswisseling, uitdroging, organische belasting (rottend blad/plantenmateriaal) en een wisselend zuurstofgehalte. Dit in tegenstelling tot veel van hun potentiële predatoren (zoals roofkevers, libellenlarven, waterwantsen, vissen en amfibieën), die dergelijke milieus vermijden. Omdat de concurrentiekracht van larven van steekmuggen relatief laag is zou de aanwezigheid van predatoren snel leiden tot een sterke afname in aantallen. In de genoemde dynamische milieus zijn de larven relatief veilig voor predatie.

\section{Voldoende voedsel}

Het voedselaanbod voor steekmuglarven kan bestaan uit dierlijke micro-organismen, algen en plantenresten. Het voedselaanbod is relatief hoog in voedselrijk en met afgestorven plantenmateriaal en blad belast water. Tijdelijke wateren in moerasgebieden bevatten waarschijnlijk altijd een overmaat aan geschikt voedsel voor moerassteekmuggen.

\section{Voldoende grote aanvangspopulatie}

Voor het ontstaan van overlast is beslissend hoeveel en op welke hoogte eitjes zijn afgezet. Dat betekent dat de hydrologische situatie, vooral de wateromstandigheden in het voorjaar, van groot belang is bij eventuele overlast vorming. Een hoge voorjaars(grond)waterstand leidt tot ei-afzetting op een hoger niveau in de natte oeverlijn. Dit heeft tot gevolg dat in eventueel daaropvolgende droge jaren de eitjes niet door het water bereikt worden. In dergelijke jaren zal geen overlast ontstaan. Echter in een daaropvolgend nat jaar waarbij de eitjes wel door water bereikt worden zullen alle aanwezige eitjes (uit meerdere voorgaande jaren) wel en gelijktijdig tot ontwikkeling komen. Deze ontwikkeling van larven en poppen en hun emergentie is vergaand gesynchroniseerd door de identieke startomstandigheden in de habitat met als resultaat talrijk en gelijktijdig optreden. Hoge aantallen zijn waargenomen, bijvoorbeeld onder vergelijkbare klimatologische omstandigheden in Duitsland in maart-mei(optimum)-juni en middeneind juli-september. De mei-juni periode komt overeen met de waarnemingen in Griendtsveen. De neerslag frequentie en intensiteit bepalen het aantal optredende generaties, meestal slechts 1 tot maximaal 3 .

Perceptie van de omwonenden

In 2015 is een enquête onder de bewoners van het dorp Griendtsveen gehouden. Hierbij werd overlast omschreven in 6 klassen (Tabel 3.1). 
Tabel 3.1: Omschrijving van de mate van overlast die bewoners ervaren (Verdonschot et al. 2015).

\begin{tabular}{ll}
\hline Overlastklasse & Omschrijving \\
\hline 1 & Geen of zo nu en dan een steek \\
2 & Regelmatig een steek of meerdere steken in kortere periode bij buiten zitten \\
3 & $>1$ keer per 2-3 jaar en langer dan 2-3 weken niet meer lekker buiten kunnen zitten \\
4 & Jaarlijks 2-3 weken niet meer lekker buiten kunnen zitten \\
5 & Jaarlijks meerdere maanden lek gestoken \\
6 & Een incidentele plaagsituatie \\
\hline
\end{tabular}

Omdat de bewoners in 2015 expliciet aangaven overlast te hebben ervaren en in de jaren daarna minder zou 2015 als indicatief jaar voor overlast kunnen worden aangehouden.

In hoofdstuk 2 is de habitat van de larven van de veenmoerassteekmug op basis van waarnemingen over de jaren 2015-2020 nader beschreven. Hierbij is geen aandacht gegeven aan de dichtheid van parasieten en predatoren omdat de langdurig tijdelijke poeltjes nauwelijks predatoren bevatten. Wat de andere randvoorwaarden betreft voldoen poeltjes in een open berkenbos met pijpenstrootje als ondergroei aan de eisen van deze soort.

\subsection{Ruimtelijke verdeling van de gewone veenmoerassteekmug (A. cinereus)}

De monitoringslocaties zijn gedurende de zes meetjaren zoveel mogelijk constant gehouden. Echter dit was niet altijd mogelijk waardoor sommige verschuivingen in aantallen een gevolg waren van de ligging van de locatie. De meeste locaties geven echter een duidelijke reflectie van veranderingen in de omstandigheden in het gebied en het weer. Per jaar is het maximum aan individuen van de veenmoerassteekmug $A$. cinereus per locatie gebruikt. De 18 locaties zijn gegroepeerd naar 4 groepen: $\mathrm{Rn}$ - rand van het natuurgebied, Rd - rand van het dorp, Do - dorp en A - apart (locatie 18). De groepen zijn bepaald op basis van de jaarlijkse aantallen steekmuggen en de geografische ligging. Er is hierbij uitgegaan van een redelijk gelijk aanvliegen van volwassen steekmuggen naar de rand van het natuurgebied, de 'oversteek' naar de bebouwing aan de rand van het dorp en vervolgens naar de dichter bebouwde zones in het dorp. Locatie 18 aan de oostzijde van het Kanaalbos is apart gehouden. De resultaten zijn in boxplots (Figuur 3.1 en 3.2) en tabellen (Tabel 3.1 en 3.2) weergegeven.

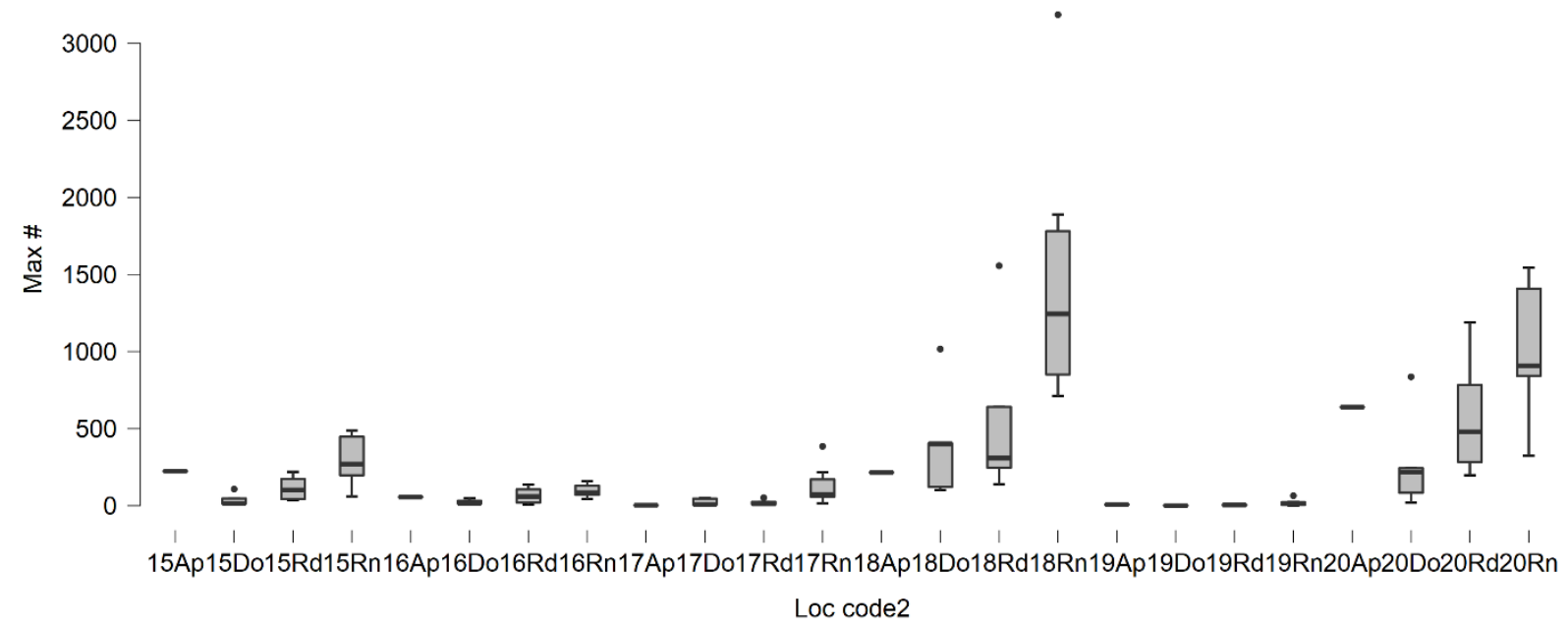

Figuur 3.1: Maximum aantallen individuen (Max. \#) per jaar per locatie van de veenmoerassteekmug ( $A$. cinereus) waarbij de individuele locaties (Loc code2) zijn gegroepeerde naar 4 groepen: $R n$ - rand van het natuurgebied, $R d$ - rand van het dorp, Do - dorp en A - apart (locatie 18). 


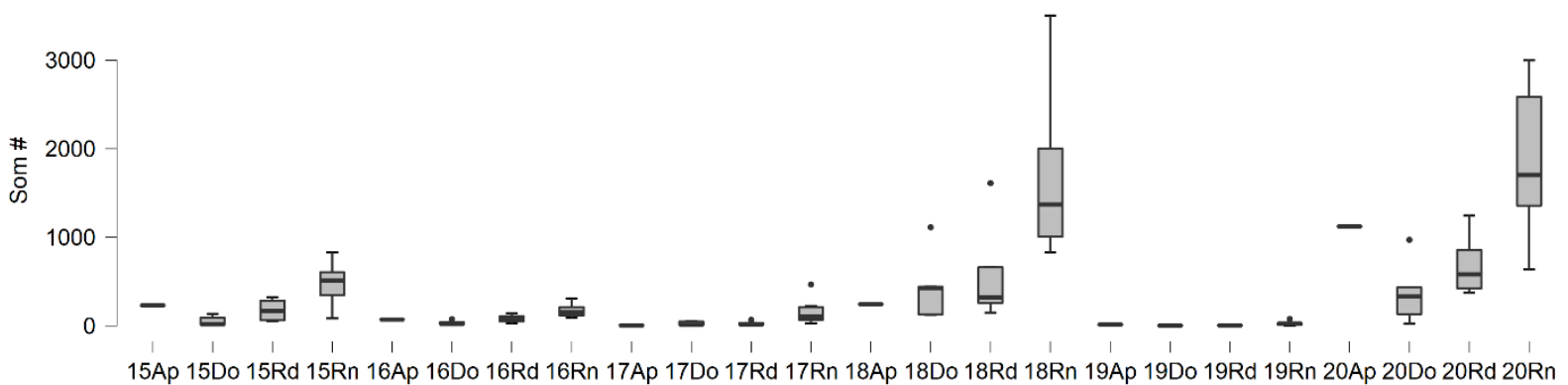
Loc code2

Figuur 3.2: Som van het aantal individuen (som \#) van de veenmoerassteekmug (A. cinereus) per jaar per locatie waarbij de individuele locaties (Loc code2) zijn gegroepeerde naar 4 groepen: $R n$ - rand van het natuurgebied, $R d$ - rand van het dorp, Do - dorp en A - apart (locatie 18).

Tabel 3.1: De mediane waarden (en maximum, 75- en 25-percentiel en minimum) van het maximum aantal individuen per jaar per locatie van de veenmoerassteekmug (A. cinereus) waarbij de individuele locaties zijn gegroepeerd naar 3 groepen: $R n$ - rand van het natuurgebied, $R d$ - rand van het dorp, Do dorp. Locatie $A$ - apart (locatie 18) is niet opgenomen.

\begin{tabular}{llllllll}
\hline & & $\mathbf{2 0 1 5}$ & $\mathbf{2 0 1 6}$ & $\mathbf{2 0 1 7}$ & $\mathbf{2 0 1 8}$ & $\mathbf{2 0 1 9}$ & $\mathbf{2 0 2 0}$ \\
\hline Rand natuur & max & 488 & 160 & 385 & 3184 & 65 & 1544 \\
& 90-perc. & 463 & 160 & 267 & 2277 & 41 & 1449 \\
& 75-perc. & 448 & 130 & 171 & 1780 & 23 & 1408 \\
& mediaan & 270 & 84 & 74 & 1244 & 14 & 908 \\
& 25-perc. & 198 & 71 & 58 & 851 & 5 & 842 \\
& 10-perc. & 138 & 59 & 27 & 765 & 2 & 607 \\
& min & 60 & 44 & 16 & 712 & 1 & 324 \\
\hline Rand dorp & max & 220 & 136 & 52 & 1556 & 8 & 1188 \\
& 90-perc. & 201 & 124 & 41 & 1190 & 7 & 1026 \\
& 75-perc. & 174 & 106 & 25 & 641 & 6 & 783 \\
& mediaan & 102 & 60 & 13 & 309 & 5 & 480 \\
& 25-perc. & 44 & 20 & 9 & 247 & 3 & 284 \\
& 10-perc. & 39 & 14 & 8 & 183 & 2 & 232 \\
& min & 36 & 9 & 8 & 140 & 1 & 198 \\
\hline morp & max & 108 & 48 & 51 & 1016 & 3 & 836 \\
& $90-$-perc. & 84 & 42 & 49 & 771 & 3 & 599 \\
& 75-perc. & 47 & 32 & 46 & 404 & 2 & 244 \\
mediaan & 14 & 16 & 8 & 402 & 1 & 219 \\
25-perc. & 13 & 15 & 8 & 121 & 1 & 84 \\
10-perc. & 9 & 13 & 4 & 110 & 1 & 46 \\
min & 7 & 12 & 2 & 102 & 1 & 20 \\
\hline
\end{tabular}

Tabel 3.2: De mediane waarden (en maximum, 75- en 25-percentiel en minimum) van de som van het aantal individuen per jaar per locatie van de veenmoerassteekmug (A. cinereus) waarbij de individuele locaties zijn gegroepeerde naar 3 groepen: $R n$ - rand van het natuurgebied, $R d$ - rand van het dorp, Do dorp. Locatie $A$ - apart (locatie 18) is niet opgenomen.

\begin{tabular}{llllllll}
\hline & $\mathbf{2 0 1 5}$ & $\mathbf{2 0 1 6}$ & $\mathbf{2 0 1 7}$ & $\mathbf{2 0 1 8}$ & $\mathbf{2 0 1 9}$ & $\mathbf{2 0 2 0}$ \\
\hline Rand natuur & max & 829 & 306 & 466 & 3504 & 76 & 2999 \\
& 90-perc. & 762 & 245 & 296 & 2518 & 48 & 2956 \\
& 75-perc. & 605 & 210 & 210 & 2004 & 30 & 2586 \\
& mediaan & 510 & 152 & 104 & 1370 & 24 & 1702 \\
& 25-perc. & 346 & 115 & 68 & 1003 & 11 & 1356
\end{tabular}




\begin{tabular}{llllllll} 
& 10 -perc. & 218 & 99 & 42 & 939 & 2 & 1005 \\
& min & 85 & 93 & 24 & 828 & 1 & 636 \\
\hline Rand dorp & max & 323 & 138 & 66 & 1610 & 9 & 1244 \\
& 90 -perc. & 308 & 126 & 52 & 1231 & 8 & 1089 \\
& 75 -perc. & 286 & 109 & 32 & 661 & 7 & 856 \\
& mediaan & 169 & 77 & 16 & 319 & 5 & 581 \\
& 25-perc. & 62 & 47 & 11 & 257 & 3 & 420 \\
\hline Dorp & 10-perc. & 55 & 33 & 10 & 192 & 2 & 394 \\
& min & 51 & 24 & 9 & 148 & 1 & 376 \\
\hline max & 134 & 74 & 51 & 1112 & 3 & 970 \\
& $90-$ perc. & 117 & 60 & 49 & 844 & 3 & 755 \\
& $75-$-perc. & 91 & 39 & 47 & 441 & 2 & 434 \\
& mediaan & 18 & 20 & 10 & 426 & 1 & 330 \\
& 25-perc. & 14 & 18 & 8 & 126 & 1 & 132 \\
& $10-$ perc. & 12 & 16 & 5 & 124 & 1 & 66 \\
min & 11 & 14 & 3 & 123 & 1 & 22 \\
\hline
\end{tabular}

Er is een duidelijk afname in de aantallen individuen van de veenmoerassteekmug tussen de rand van het natuurgebied en het dorp. Echter naarmate het aantal in de rand van het natuurgebied toeneemt, bereikt ook een verhoogd aandeel (een sterke lineaire relatie) het dorp (Figuur 3.3). Van het aantal in de randzone van het natuurgebied bereikte gemiddeld over de zes jaren $29 \%( \pm 12 \%)$ de rand van het dorp en bereikte $13 \%( \pm 10 \%)$ de kern van het dorp.

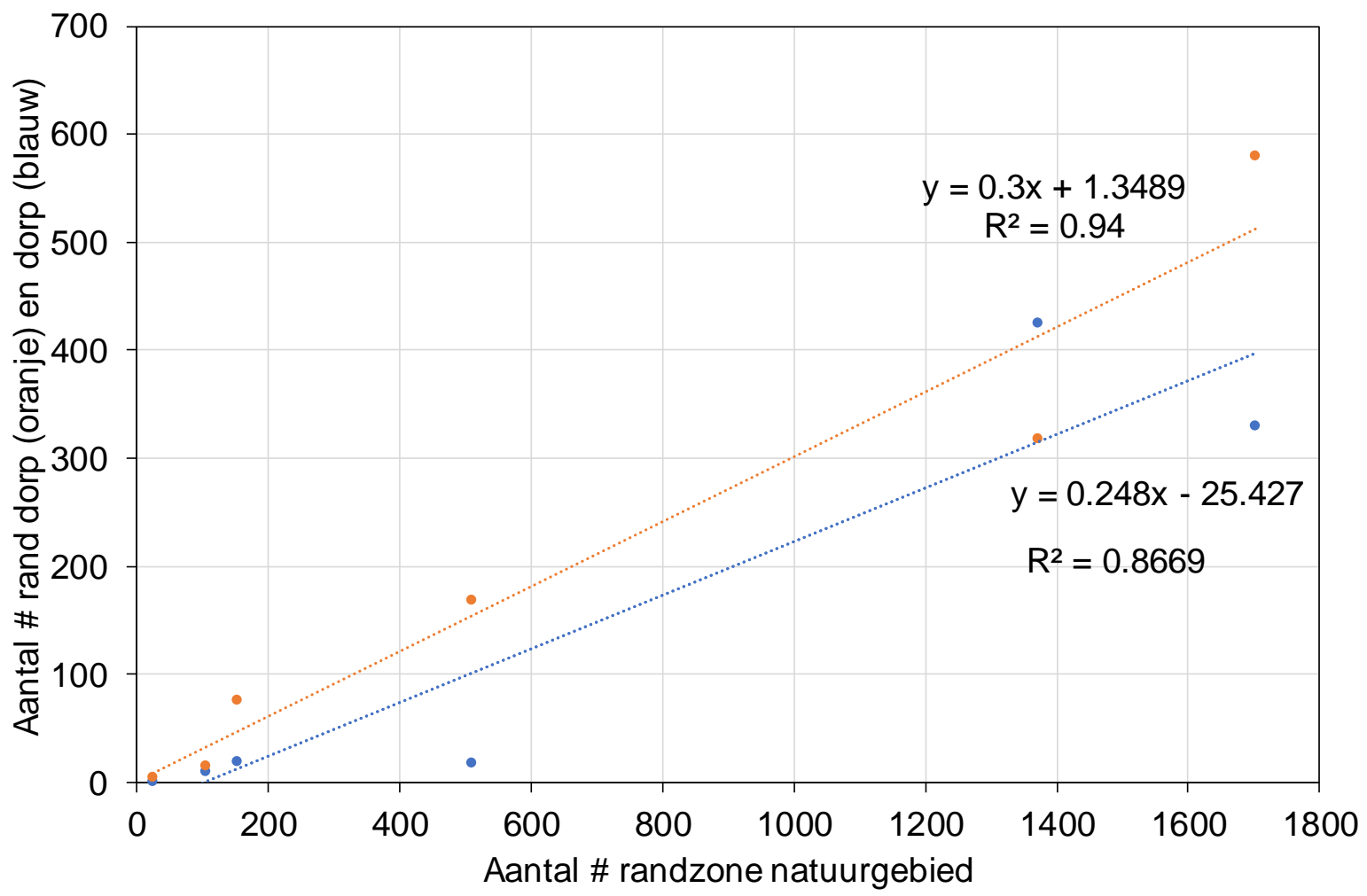

Figuur 3.3: De relatie tussen het aantal individuen (\#) van de veenmoerassteekmug gevangen aan de rand van het natuurgebied t.o.v. het aantal aan de rand van het dorp (oranje) en in het dorp (blauw). 


\subsection{Wanneer is sprake van overlast?}

Op basis van de waarnemingen en de ruimtelijke verdeling over de jaren 2015-2020 kan een nadere indicatieve kwantificering van overlast worden aangegeven. Hierbij moet vooraf worden aangetekend dat overlast een relatief begrip is en ongelijk is aan een indicatieve kwantificering van de aantallen in de maatregelfase. Voor de indicatie van aantallen die overlast geven zijn de volgende uitgangspunten genomen:

- Omdat de enquête in 2015 aangaf dat in dat jaar door de bewoners overlast is opgetreden kan 2015 als indicatief jaar voor de kwantificering van overlast worden aangemerkt. Omdat ook in 2014 en mogelijk in de jaren daarvoor eveneens van overlast sprake was kan deze indicatie mede daardoor zijn beïnvloed, echter zijn we na 2015 van dit moment uitgegaan.

- $\quad$ Om de relatie met het natuurgebied direct te behouden wordt voorgesteld de aantallen verzameld in de randzone van het natuurgebied als leidend te nemen omdat ze een directe reflectie zijn van het natuurgebied en er van de randzone de meeste en onderling best vergelijkbare metingen van beschikbaar zijn.

- Om overlast te kwantificeren gebruiken we de mediaan als waarde en de 25- en 75-percentielen als spreiding (onzekerheidsmarge).

Dit zou betekenen dat wanneer op de 8 meetlocaties in de randzone van het natuurgebied rondom het dorp Griendtsveen het gemiddeld maximum aantal individuen per locatie meer dan 270 (met een onzekerheidsmarge tussen 198 en 448) volwassen steekmuggen van de soort Aedes cinereus worden gevangen er sprake is van overlast. Een alternatief is overlast koppelen aan de gemiddelde som van het aantal individuen per locatie van boven de 510 met een marge van 346 tot 605 . Een belangrijke vraag hierbij is wel hoe de overlast ervaring was in de jaren 2018 en 2020, gezien de veel hogere aantallen die die jaren. Een steekproef of enquête onder de bewoners kan mogelijk hier enig licht op werpen. 


\section{Mogelijke beheer en interventiemaatregelen}

\subsection{Inleiding}

Deze paragraaf gaat in op de vraag of er (extra) richtlijnen nodig voor het beheer met speciale aandacht voor opties om tussentijds bij te stellen. Hierbij staat aandacht voor passende maatregelen mochten er broedplaatsen ontstaan centraal. Om fijnschalig- of detailbeheer effectief te kunnen uitvoeren is ervaring nodig. Het kan in de eerste jaren zo zijn dat pas gericht beheerd kan worden in het jaar na (gemeten) overlast.

Gezien de waarneming dat de tijdens de maatregelfase in drie van de zes jaar hoge aantallen veenmoerassteekmuggen optraden zijn verbeteringen gewenst. Er zijn drie componenten bepalend voor de ontwikkeling van de populaties van de veenmoerassteekmug $A$. cinereus:

1. De weersomstandigheden.

2. De hydrologische omstandigheden in het natuurgebied dat het dorp omringt.

3. De 'structuur' (hoogte, bodemsamenstelling, vegetatie en terreinaccidentatie) van het natuurgebied.

De combinatie van deze factoren bepaalt of de in het moerasgebied aanwezige droogvallende depressies langdurig gevuld zijn met water en daarmee of de populaties tot hoge dichtheden komen. Een voorbeeld zijn de weersomstandigheden tussen de natte zomermaanden in 2016 en de droogte in 2018, 2019 en 2020. Deze extremen hebben effecten op het verloop van de populatiedichtheid van de veenmoerassteekmug laten zien. Aan de weersomstandigheden valt weinig te veranderen aan beide andere componenten wel.

Maatregelen in het natuurgebied die de aantallen steekmuggen verminderen kunnen gericht zijn op:

1. Het verkleinen van het oppervlak van de broedgebieden.

2. Het beperken van de bereikbaarheid van het dorp voor steekmuggen.

\subsection{Het verkleinen van het oppervlak van de broedgebieden}

Het verkleinen van het oppervlak aan broedgebieden betekent het terugdringen van de aantallen uitvliegende individuen door het beperken van het oppervlak langdurig tijdelijk water. Het beheer na de maatregelfase dient mede gericht te zijn op het voorkomen van grotere oppervlakken met (langduriger) tijdelijke wateren (meerdere weken tot 6 maanden nat) en natte habitattypen (plas-dras situaties en bos en opslag in geaccidenteerd terrein).

Uiteraard begint het met het kennen van de ligging van de broedgebieden. In 2015 is een visuele schatting van de kaart met toekomstig tijdelijk water op basis van grondwater in de winter aan maaiveld. Deze inschatting duidde op een oppervlak van 20-30\% van het natuurgebied wat daarmee potentieel habitat voor de veenmoerassteekmug levert. Dit betekent niet dat al deze tijdelijke wateren ook steekmuggen 'leveren'. Wateren kunnen te tijdelijk zijn of in verbinding staan met permanente wateren. Een alternatief is het areaal begroeid met pijpenstrootje en berk te bepalen. Een derde alternatief is de nieuwe grondwaterpeilen nauwkeurig monitoren en koppelen aan de hoogtekaart om zo het areaal water op maaiveld te bepalen. Het is duidelijk geworden dat dergelijke arealen redelijk verdeeld over het natuurgebied liggen wat overeenstemt met de resultaten van de vangsten van volwassen steekmuggen die ook een herkomst uit de drie richtingen aangeven. Vervolgens zijn verschillende beheermaatregelen mogelijk:

\section{- Peilbeheer}

Door de compartimentering kan, indien mogelijk, het beheer per compartiment worden gericht op het nauwkeurig sturen op waterpeil. Waarschijnlijk moet het beheer van de compartimenten aan de rand van het natuurgebied anders zijn dan die verder in het gebied. In het gebied dient het water jaarrond tot maaiveld te reiken voor de veenmosontwikkeling. Afhankelijk van de kans op ontstaan van broedplekken kan de waterhuishouding in randcompartimenten gestuurd worden met permanent hoge grondwaterpeilen zodat de langdurig tijdelijke wateren permanent worden en ruimte geeft aan rovers of juist jaarrond geen of nauwelijks water boven maaiveld. Tegelijk kan ook verfijnd bijgestuurd worden met greppels of met onderverdeling in deelcompartimenten wanneer gebiedsdelen te veel van de gewenste natheid afwijken. Een voorbeeld is de afwatering door de slenk van compartiment XIV 
naar XV waar de inrichting en het onderhoud zorgvuldig gericht moet zijn op het onder maaiveld houden van het water na het vroege voorjaar en eventueel achterblijvende restpoelen voorkomen worden door maaibeheer. Eventueel andere aanvullende waterhuishoudkundige maatregelen kunnen worden ingebracht op het moment dat de broedplekken in kaart zijn gebracht.

- $\quad$ Fijnschalige herinrichting

Gebieden met laag liggende delen met langdurig tijdelijk water worden waar mogelijk onderling verbonden en in maart-april worden ze zoveel mogelijk afgewaterd m.a.w. het peil wordt tot of onder maaiveld gebracht (eventueel m.b.v. afwaterende greppels).

- Benutten van waterberging

Een aanvullende algemene maatregel kan het bergen van overtollige winterneerslag zijn op open water en in de compartimenten (hoger peil toelaten), en dit water te gebruiken om in de zomer te droge gebieden te suppleren om zo sterke waterstandfluctuaties te beperken en toch gebiedseigen water te behouden en gebruiken. Aanvullend bij deze en de vorige maatregelcategorie is het opnieuw afstemmen van het oppervlaktewaterpeil op de grootste oppervlakken hoger - lager gebied en dat betekent dat het peil kan worden opgezet, gelijk blijven of verlaagd worden ten opzichte van de huidige streefwaarde. Soms kan water ook worden geborgen in de bodem. Ook wordt geëvalueerd, bij voorkeur op basis van monitoringsgegevens, of de waterstandsfluctuatie in de compartimenten binnen de $60-80 \mathrm{~cm}$ valt, afhankelijk van de verschillen in hoogte en de benodigde beperking van de dynamiek.

- Vaststellen broedgebieden

Op basis van de metingen nemen we aan dat broedplaatsen verspreid over het gehele noordelijke deel van het natuurgebied voorkomen. De uitgevoerde LIFE+ maatregelen hebben mogelijk nu al invloed op de grondwaterpeilen maar met het daadwerkelijk instellen van de streefpeilen wordt pas duidelijk wat de nieuwe situatie wordt. Bijkomend effect was de lekkende kanaalkade. Door het in het verleden al stoppen van wateraanvoer vanuit Helenavaart vielen de wijken vaker droog. Door de lekken in de kade vernatte een deel van het gebied ten zuiden van het dorp. Hoe ver deze invloed reikte en wat dat voor de steekmuggen betekende is onbekend. In 2015 gaven we al aan dat in het noordelijk deel van de Driehonderd Bunders met grote onzekerheid 5-10\% toename in tijdelijke wateren zou gaan optreden, echter met een aan een verfijnde inrichting aangepast waterbeheer kunnen deze broedgebieden juist sterk in oppervlak worden verminderd. Dat betekent dat de effecten van maatregelen sterk afhangen van de details waarmee ze worden geïmplementeerd. Om deze reden wordt aanbevolen de potentiële broedgebieden nauwkeuriger in kaart te brengen. Aanvullende maatregelen kunnen dan met precisie doel- en kosteneffectief worden uitgewerkt en uitgevoerd. Het hiermee verkregen inzicht draagt bij aan betere keuzes met een meer duurzame oplossing voor zowel de veenmosontwikkeling als de vermindering van steekmuggen op de lange termijn.

\subsection{Veenmosontwikkeling en steekmug vermindering}

Het ontwikkelen van veenmossen om hoogveenregeneratie op gang te krijgen stelt eisen aan het milieu:

- Waterdiepte maximaal $50 \mathrm{~cm}$.

- Geen droogval.

- Stabiele waterstand.

- Grondwater basisch met een stijghoogte tot de veenbasis een wegzijging van maximaal $30 \mathrm{~cm}$.

- Peilfluctuatie tot $\pm 60-80 \mathrm{~cm}$.

Het verminderen van de broedplaatsen van moerassteekmuggen vraagt om:

- Water onder of tot maaiveld of permanent boven maaiveld.

- Geen droogval.

- Stabiele waterstand.

- Oppervlak tijdelijk water minimaliseren.

Uit bovenstaande eisen blijkt dat er geen controverse is tussen veenmos ontwikkelen en steekmuggen verminderen. Integendeel veenmosontwikkeling zonder steekmuggen is goed mogelijk en vraagt om een verfijnd oppervlakte- en grondwaterbeheer. Compartimenteren was hierbij een geschikte eerste stap om een dergelijk waterbeheer mogelijk te maken, het waterbeheer zelf moet na de maatregelfase zo snel mogelijk worden geïmplementeerd. Daarna dient te worden getoetst of de (grond)waterpeilen wel stabiel genoeg zijn over voldoende oppervlak van ieder compartiment. Het is wel belangrijk te toetsen of de voorgestelde compartimentskades op de scheidingen hoog-laag komen te liggen. 


\subsection{Het beperken van de bereikbaarheid van het dorp voor steekmuggen}

Barrières kunnen de vlucht richting dorp bemoeilijken. Barrières zijn zones die voor volwassen steekmuggen ongunstig zijn (lage luchtvochtigheid, wind vrij spel). Dergelijke zones kunnen worden gerealiseerd door configuratie van de verbindingszone aan te passen. Voor het beperken van de vliegbeweging richting het dorp kunnen open corridors (grotere oppervlakken lage vegetatie (kort gras) of open water) bijdragen. Open corridors het verhogen van de invloed van wind, verlagen de luchtvochtigheid en verhogen de temperatuur in deze zone. Dit kan ten zuiden en oosten van het dorp, aan de westzijde is nauwelijks mogelijkheid voor dit type maatregelen.

De veenmoerassteekmug heeft een gerapporteerde gemiddelde vliegafstand van $1.6 \mathrm{~km}$ (Nielsen 1957). Dit betekent niet dat alle steekmuggen ook daadwerkelijk deze afstand afleggen, die kan langer en korter zijn. Steekmuggen vliegen vaak niet verder dan nodig is om hun bloedmaal te verkrijgen. Hoe verder een broedgebied van het dorp ligt, hoe kleiner het aandeel van uitgevlogen steekmuggen die tot in het dorp zullen vliegen. Hoge aantallen leiden echter tot een versterkte en wijdere verspreiding, zoals het onderzoek heeft laten zien. Wel weten nu ook dat de afname in aantallen steekmuggen vanaf de rand van het natuurgebied tot in de kern van het dorp over enkele honderden meter groot is. Door in de verbindingszones, die met meer precisie gesitueerd kunnen worden op het moment dat de broedgebieden gelokaliseerd zijn, zowel 'barrières' en 'schuilplaatsen' aan te brengen kunnen volwassen steekmuggen als het ware gestuurd worden. Schuilplaatsen zijn plaatsen die voor volwassen steekmuggen juist aantrekkelijk zijn. Schuilplaatsen zijn meestal gesloten vegetaties (hoog opgaande ruigtevegetaties, struiken, bomen). Aanbevolen wordt verbindingszones pas in te richten nadat de broedplaatsen zijn aangepakt maar de resultaten onvoldoende blijken.

\subsection{Samenvatting}

Samenvattend betekent dit dat het toekomstig waterbeheer zich dient te richten op het door de jaren heen op stabiel niveau houden van het waterpeil over een zo groot mogelijk oppervlak in het natuurgebied en vooral in de risicozone rondom Griendtsveen. Dit kan zowel veenmosontwikkeling als steekmugvermindering tot gevolg hebben. Voor beide is het uiterst belangrijk om waterverlies uit het gebied te voorkomen. Dit kan door met precisie waterbeheer het zoveel mogelijk vasthouden van het gebiedseigen water, de wegzijging te beperken door buffering van de laag gelegen gebiedsdelen of de gebiedsdelen met een lage grondwaterstand, indien nodig met inzet van bemaling. Bij het uitvoeren van steekmug verminderende maatregelen dient steeds te worden bedacht dat delen van het moerasgebied of ook in droge jaren nat kunnen worden gehouden of dat een waterpeil onder of tot aan maaiveld, m.a.w. het voorkomen van tijdelijke inundaties, wordt gehandhaafd. Bij het beheer kunnen de weeromstandigheden niet worden bijgestuurd maar er kan wel op worden ingespeeld.

Het gebied Mariapeel is nog volop in ontwikkeling. De uitvoering van het peilbeheer in de Mariapeel en vraagstukken rondom de nog steeds zeer wisselende waterhuishouding in het Kanaalbos en zuidelijk daarvan gelegen gebiedsdelen leiden tot veranderingen of verdienen aandacht. Ook gaan aan de westzijde door de inrichting van Leegveld mogelijk veranderingen in de Deurnsche Peel plaats vinden. De interne en externe ontwikkeling zijn aanleiding tot de verwachting dat mogelijke overlast op steekmuggen in het dorp voorlopig blijft bestaan. De aantallen steekmuggen zijn een goede graadmeter voor de mate van stabilisering van de waterhuishouding. Daarom wordt aanbevolen om enige vorm van monitoren van volwassen steekmuggen de komende jaren voort te zetten. Daarmee kan regelmatig geadviseerd worden over effecten van maatregelen of voorstellen voor aanvullende maatregelen (of bijsturing). Het karteren van larven/broedgebieden is afhankelijk van de vraag of doorgegaan wenst te worden met het lokaliseren van bronnen van overlast of dat de aandacht vooral uitgaat naar overall effecten van de ingezette ontwikkelingen in het gehele gebied. 


\section{Monitoring tijdens beheerfase}

\subsection{Inleiding}

In hoofdstuk 4 is verschillende keren verwezen naar het uitvoeren van metingen om in te kunnen spelen op de ontwikkelingen van de veenmoerassteekmug. Met het regelmatig meten van de populatiedichtheid en indien nodig de locatie van broedgebieden is adaptief detailbeheer mogelijk. Nu de maatregelfase bijna beëindigd is, de kanaalkade gerepareerd wordt en de peilen ingesteld kunnen worden/zijn start de zogenaamde beheerfase. Omdat sommige ingrepen nog moeten worden uitgevoerd en omdat het gebied zich enigszins moet instellen op de nieuwe situatie wordt voorgesteld om in 2023 te starten met het aangepaste meetprogramma.

\subsection{Monitoring in de beheerfase}

Volwassen steekmuggen

Voor de nabije toekomst is het vooral belangrijk om vast te stellen of in jaren met hoge aantallen veenmoerassteekmuggen deze niet de voorgestelde range van overlast overschrijden. Daarnaast hebben we geleerd hoe de aantallen steekmuggen zich vanuit de rand van het natuurgebied naar het dorp veranderen. Ook hebben we gezien dat de aantallen per jaar verschillen en dat in ongeveer de helft van de 6 meetjaren hogere aantallen optraden. Wat we hierbij niet met zekerheid konden vaststellen was wat de precieze oorzaak van hoge aantallen was. Hierin speelden vooral het weer maar ook de gebiedshydrologie en terreinomstandigheden in op de steekmugpopulatie-ontwikkeling. Parallel aan de monitoring van stekende insecten is het zinvol om ook iedere keer een enquête onder de bewoners te houden om zo beter de link te leggen tussen (het moment van) hoogte van aantallen muggen en mate van ervaren overlast.

Voorgesteld wordt om 12 locaties te gaan monitoren op volwassen steekmuggen en knutten (Figuur 5.1). Per locatie wordt bepaald hoe vergelijkbaar de begroeiing nog is met de meting in 2020 en met de andere locaties. Om een zo groot mogelijke vergelijkbaarheid tussen de locatie te bereiken kunnen de aangegeven locaties nog enigszins verschuiven. Er wordt weer maandelijks gemonitord met dezelfde, of indien nieuwe ontwikkelingen dat vragen, aangepaste meetmethoden. Indien er geen aanleiding is wordt om het jaar gemeten. Mocht echter 2023 lage aantallen opleveren of mochten vroeg in het voorjaar al overlast worden gesignaleerd dan wordt ook in 2024 gemeten. In andere gevallen wordt het 2025.

Het wordt aanvullend geadviseerd om ook enkele meetlocaties voorbij de $2 \mathrm{~km}$ zone in te richten om een beeld te krijgen van de aantallen in het natuurgebied (bij voorkeur een compartiment met een stabiel en een compartiment met een meer instabiel waterpeil). Indien de steekmuggen verder vliegen dan $2 \mathrm{~km}$ en toch van dieper uit het gebied komen kan hiermee beter inzicht worden verkregen.

Larven en broedplaatsen

Bij signalering van overlast in het dorp is het te laat om in dat jaar nog broedplaatsen te gaan zoeken. Daarnaast is gebleken dat het meer gebiedsdekkend karteren van aantallen larven erg arbeidsintensief is door de lastige toegankelijk het van het natuurgebied. Daarom stellen we de volgende aanpak voor:

1. Het op basis van luchtfoto's en modelberekeningen (grondwater aan het einde van de winter op maaiveld) duiden waar potentieel habitat voor de veenmoerassteekmug ligt.

2. Het op basis van een recente vegetatiekartering en of luchtfoto's lokaliseren van de arealen begroeid met pijpenstrootje en berk.

3. Het monitoren van de grond- en oppervlaktewaterpeilen per compartiment en deze metingen koppelen aan de terreinaccidentatie (detailhoogtekaart AHN) in betreffend compartiment.

4. Het koppelen van de resultaten van punt 1, 2 en 3 .

5. Het steekproefsgewijs bezoeken van deelarealen en het daarbij vaststellen van het aandeel tijdelijk water in combinatie met het op larven bemonsteren van een aantal poeltjes. 


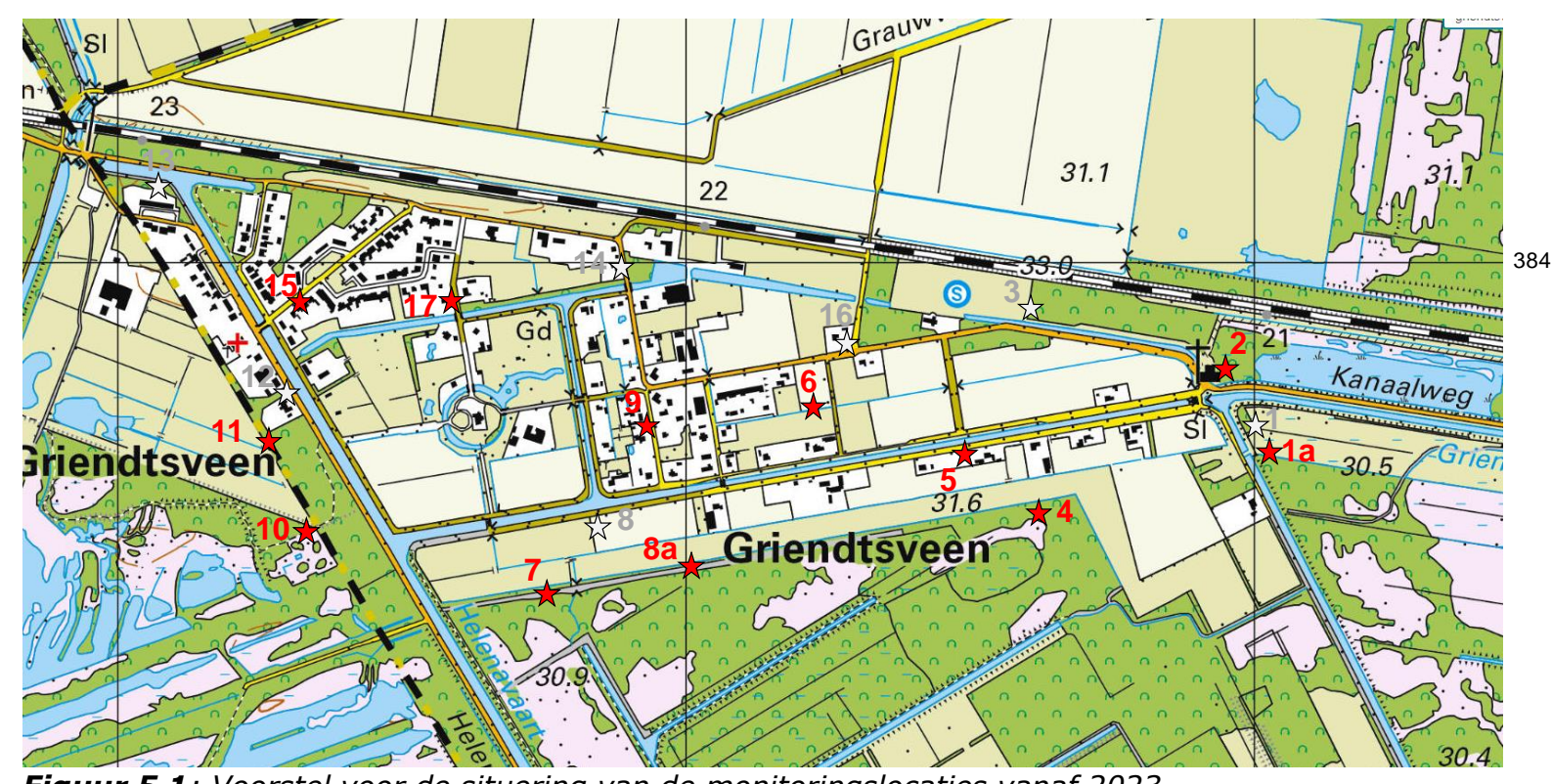

Figuur 5.1: Voorstel voor de situering van de monitoringslocaties vanaf 2023. 


\section{Conclusies}

In 2015, het eerste jaar van onderzoek, is met metingen vastgesteld dat de door de bewoners van Griendtsveen gesignaleerde overlast (enquêteresultaat) van steekmuggen op dat moment reëel was. De overlast blijkt vooral door de soort Aedes cinereus (veenmoerassteekmug) veroorzaakt. De larven ontwikkelden zich in langdurig water bevattende tijdelijke wateren in de natuurgebieden de Mariapeel, de Deurnsche Peel, het Kanaalbos en het Grauwveen. In de jaren daarna is de ontwikkeling van de steekmuggen- en knutten populaties gevolgd.

Een vergelijking van de veenmoerassteekmug populaties liet zien dat de populaties beïnvloed werden door de combinatie van vooral de neerslag en in mindere mate de temperatuur en de terreinomstandigheden. We vermoeden dat in 2015 het gebied in de nabijheid van het dorp waarschijnlijk natter was dan in de jaren daarna. In 2018-2019 kan daarnaast de lekkende kade een additionele rol hebben gespeeld bij de hoge aantallen larven in het aangrenzend compartiment.

Meer in detail trad tussen 2015-2017 een afname van de aantallen van de veenmoerassteekmug $A$. cinereus op en namen de aantallen van de soort $O$. punctor in het gebied toe terwijl $A$. cinereus in 2018 en 2020 weer domineerde. $A$. cinereus is een tolerantere soort met een breder habitatspectrum terwijl $O$. punctor vroege voorjaarssoort is s die vaker op koelere, zuurdere, beschaduwde, tijdelijk water bevattende locaties voorkomt.

De hoge aantallen volwassen steekmuggen traden niet jaarlijks op precies dezelfde locatie in en rondom het dorp op. Dit duidt erop dat de verspreiding van de individuen variatie vertoont mogelijk deels samenhangt met de ligging van de langdurig tijdelijke wateren wat weer samenhangt met de combinatie van de waterhuishouding van het gebied en de weersomstandigheden.

Het toekomstige beheer van de randzones van het natuurgebied moet gaan inspelen op extreme weersomstandigheden. Dit kan met het sturen op de hydrologische omstandigheden (peilen) en de 'structuur' van het gebied. Het belangrijkste doel in het gebied is het stabiel op peil (nat) houden en of droog houden van de moerassige laagtes. Stabiel op peil houden betekent het zoveel mogelijk op peil houden van oppervlaktewater in het gebied en het zoveel mogelijk aan maaiveld houden van het grondwater in het gebied. Daarmee wordt droogval zoveel mogelijk voorkomen en dat leidt op haar beurt weer tot een vermindering van de kans op overlast door steekmuggen.

De soms zeer intensieve inventarisatie van larven, en vooral van de veenmoerassteekmug $A$. cinereus, heeft laten zien dat deze soort zeer verspreid over het gebied voorkomt. Hoe ver precies deze steekmug soort zich vanuit het gebied tot in het dorp kan verplaatsten is vooralsnog onbekend. Ook weten we niet of in natte jaren de dichtheden overal in het gebied in gelijke mate toenemen. Daarnaast zet de soort eitjes af op de natte randzone van tijdelijke wateren. Een kernvraag is bij welke peilen (welk gedetailleerd peilbeheer) tijdens een natte periode in de winter in combinatie met stijgende grondwaterpeilen de eitjes uitkomen die in jaren daarvoor zijn afgezet maar niet meer onder water zijn geraakt door de opeenvolgende droge perioden.

Aanbevelingen zijn opgenomen om met het regelmatig meten van de populatiedichtheid van volwassen steekmuggen en indien nodig de lokaliseren van broedgebieden is adaptief detailbeheer mogelijk en wordt het streven naar het voorkomen van overlast ondersteund. 


\section{Literatuur}

Verdonschot, P.F.M., Schmidt, G., Leeuwen, P.H.J. van \& Schot, J.A. (1988). Steekmuggen (Culicidae) in de Engbertsdijksvenen. RIN, Leersum, rapport 88/31:1-109.

Verdonschot Piet F.M. (2009). Verkenning van de steekmuggen- en knutten-problematiek bij klimaatverandering en vernatting. Alterra rapport $1856.76 \mathrm{pp}$.

Verdonschot P.F.M. \& Besse-Lototskaya A.A. (2012). Leidraad Risicomanagement Overlast Steekmuggen en Knutten: Toelichting op de Leidraad. Alterra-rapport 2298, 59 pp.

Verdonschot P.F.M. \& Besse-Lototskaya Anna A. (2014). Quick-scan risico-analyse op stekende insecten in de Mariapeel. Notitie Zoetwaterecosystemen, Alterra, Wageningen. $57 \mathrm{pp}$.

Verdonschot P.F.M., Dekkers Dorine D. \& Besse-Lototskaya Anna A. (2015). Stekende insecten Griendtsveen. Situatie 2015. Alterra-rapport 2680. 64 pp.

Verdonschot, P.F.M. \& Dekkers, T.B.M. (2017) Stekende insecten Griendtsveen 2016. Notitie Zoetwaterecosystemen, Wageningen Environmental Research, Wageningen UR, Wageningen. 81 pp.

Verdonschot P.F.M. \& Dekkers T.B.M. (2018). Stekende insecten Griendtsveen 2017. Notitie Zoetwaterecosystemen, Wageningen Environmental Research, Wageningen UR, Wageningen. 57 pp.

Verdonschot P.F.M. \& Dekkers T.B.M. (2019). Stekende insecten Griendtsveen 2015-2018. Notitie Zoetwaterecosystemen, Wageningen Environmental Research, Wageningen UR, Wageningen. 59 pp.

Verdonschot P.F.M. \& Dekkers T.B.M. (2019). Stekende insecten Griendtsveen 2018. Notitie Zoetwaterecosystemen, Wageningen Environmental Research, Wageningen UR, Wageningen. 54 pp.

Verdonschot P.F.M. (20209). Stekende insecten Griendtsveen 2019. Notitie Zoetwaterecosystemen, Wageningen Environmental Research, Wageningen UR, Wageningen. 32 pp.

Verdonschot P.F.M. \& van Noord A. (2021). Stekende insecten Griendtsveen 2020. Notitie Zoetwaterecosystemen, Wageningen Environmental Research, Wageningen UR, Wageningen. 23 pp. 


\section{Bijlagen}

\subsection{Bijlage 1: Ecologie van de gewone veenmoerassteekmug (Aedes cinereus)}

De potentieel overlast veroorzakende soort is de gewone veenmoerassteekmug $A$. cinereus. De volgende tekst is gebaseerd op Verdonschot et al. (1988). De gewone veenmoerassteekmug doorloopt vier levensstadia: ei, larf (vier stadia), pop en volwassen. De habitat van $A$. cinereus verschilt tussen de eitjes, larven/poppen en volwassen dieren.

Eitjes worden afgezet op laag liggende plekken die in regenperioden onder water komen te staan. Elk eitje wordt afzonderlijk afgezet op afgevallen blad en organisch materiaal in bodemdepressies. De eitjes worden afgezet in de periode juni-september. Er worden 8 tot 106, gemiddeld 60 eieren per keer afgezet. $A$. cinereus overwintert als ei. De literatuur is niet eenduidig over het begin van de ei-ontwikkeling; bij $5-6^{\circ} \mathrm{C}$ tot $12-13^{\circ} \mathrm{C}$. De eitjes komen pas tot ontwikkeling als ze meerdere malen onder water hebben gestaan, maar meestal is dat in april. Bij circa $31^{\circ} \mathrm{C}$ sterven pas uitgekomen larven of komen de eieren in het geheel niet uit. $A$. cinereus vereist voor een ongestoorde ontwikkeling dus een relatief hogere watertemperatuur. Deze temperatuur wordt vaak pas bereikt als de eerste voorjaarspoelen alweer zijn opgedroogd. De helft van de eitjes komt uit zonder koude periode en heeft geen rustfase. Mocht een tweede generatie optreden dan komen deze eitjes bij kamertemperatuur circa twee weken na afzetting uit. Eitjes zijn vanaf oktober tot half mei aanwezig maar kunnen ook meerjarig aanwezig blijven en zijn vorst en droogte resistent.

De larven kruipen, afhankelijk van de temperatuur en de geografische positie, uit het eitje in:

Groot-Brittannië april-juni

West-Duitsland begin maart / april en nazomer

Denemarken half mei-half juni

Oost-Duitsland eind maart / midden-april en september

Polen half april-half juli

Noorwegen vanaf eind mei

De larven van $A$. cinereus kunnen in verschillende watertypen worden aangetroffen. De belangrijkste sturende factor is de permanentie van het water. $A$. cinereus heeft een voorkeur voor temporaire wateren, vooral die wateren die tot ongeveer de helft van het jaar water bevatte, zogenaamde langdurig tijdelijke watertjes. Door het (meso-)thermofiele karakter van $A$. cinereus kunnen geen kortstondige voorjaarspoelen worden bewoond, zoals de echte voorjaarssoorten (bijvoorbeeld $O$. punctor) dat wel doen. Andere belangrijke beperkende milieufactoren zijn chloride (tot een maximum van $261 \mathrm{mg} / \mathrm{I}$ ), dimensie en zuurgraad. $\mathrm{Er}$ is een duidelijke voorkeur van deze soort voor kleine wateren zoals plassen (minder dan 6 $\mathrm{m}^{2}$ en minder dan $40 \mathrm{~cm}$ diep), sloten, greppels, poelen, rivier- en veenmoerassen, oude veenderijen, slenken in venen, broekland, drassige weiden, open verlandingszones van meren en vijvers en overstromingsgebieden van beken en rivieren. Grote permanente wateren en kleipoelen met grijs en alkalien water worden gemeden. $A$. cinereus heeft een duidelijke voorkeur voor zure wateren (licht acidofiel), eventueel met veenmos (Sphagnum) begroeid. De pH-range loopt van 3.0-4.5 aan de zure tot 3.9-8,2 aan de basische kant, waaruit blijkt dat de $\mathrm{pH}$ minder bepalend is voor het voorkomen. De dichtheid van andere soorten is laag in wateren bewoond door $A$. cinereus. De optimumtemperatuur voor de larvale ontwikkeling ligt tussen 24 en $25^{\circ} \mathrm{C}$, waarbij de sterfte gering is. Een tweede generatie ontwikkelt zich sneller (hogere temperaturen), maar is minder abundant dan de eerste. Het larvestadium wordt in slechts 8-10 dagen tot circa twee maanden doorlopen, afhankelijk van de temperatuur.

Tijdens het popstadium is $A$. cinereus veel minder mobiel en voedt het dier zich niet. Dit stadium duurt slechts enkele dagen. Na de verpopping vliegen de volwassen dieren vanuit de broedplaats meestal naar bos.

Volwassen dieren van $A$. cinereus komen voor in rivierbossen, bossen, struikgewas, (riet)oevers van grote wateren, graspollen in uitgedroogde poelen, moerassen en venen. In de meer open struik/boom vegetatie en ruigtevegetaties vindt $A$. cinereus zijn optimum en is hier in de zomer steeds abundant aanwezig. Overdag rusten de volwassen dieren op deze vochtige beschaduwde en relatief koele plaatsen. In deze habitats worden ze vaak samen met $O$. cantans en $O$. punctor gevonden. In open terrein worden overdag geen vrouwtjes aangetroffen. De volwassen dieren vliegen pas op vanuit hun rustplaats als ze verstoord worden. Ook verplaatsen volwassen dieren zich gedurende de dag van open naar beschaduwde gebieden (rustplaatsen). De grootste activiteit van de vrouwtjes (alleen vrouwtjes hebben steekgedrag) is tijdens de avonduren en de nacht in open terrein. De dieren zijn ook actief in de ochtenduren en overdag. De volwassen dieren zijn hygrofiel (voorkeur voor vocht) en benaderen hun gastheer alleen in de vochtigste delen van de lucht, dus meestal op de benen. Ook overdag is op beschaduwde plekken de aanvlucht sterk, vooral bij hoge luchtvochtigheid, voor en na onweer en bij lichte regen. Op plaatsen waar ze overdag 
rusten kunnen ze op elk moment van de dag een prooi benaderen. $A$. cinereus zuigt bloed van zoogdieren en vogels. Na het bloed zuigen duurt het vijf tot tien dagen voordat de eieren worden afgezet. De vrouwtjes leven 3-4 maanden en sterven voor de herfst, de mannetjes echter waarschijnlijk al in juni-juli. 50\% van de totale populaties is 13 tot 19 dagen na aanvang van de emergentie uitgevlogen.

Meestal is er sprake van 1 generatie per jaar. De opgaven over het aantal generaties per jaar verschillen echter van een, twee, drie tot meerdere per jaar afhankelijk van gebied. De aanwezigheid van volwassen dieren is afhankelijk van het klimatologisch gebied:

Groot-Brittannië juni-september, max. juli

West-Duitsland half maart-midden juli

Denemarken eind mei-oktober

Oost-Duitsland

vanaf april tot midden augustus, max. half juli

Polen

Finland

mei-midden november

voorjaar 


\subsection{Bijlage 12: Ecologie van de belangrijkste soorten knutten}

Het geslacht Culicoides behoort tot de familie van de Ceratopogonidae (knutten).

Culicoides impunctatus (hoogland knut) is circa $1.4 \mathrm{~mm}$ lang en weegt circa $0.5 \mu \mathrm{g}$. Deze soort leeft in drassige, voedselarme, zure bodems, zoals (veen)moerassen en de overgangszones aan de rand van moerassen en in vochtige en natte terrestrische habitats. Slechts incidenteel is de soort nabij boerderijen verzameld. De habitat wordt vaak gekenmerkt door begroeiing met biezen, zoals zomprus en veldrus, heide en pijpenstrootje evenals de aanwezigheid van veenmossen (Sphagnum spp.). Het grondwaterniveau is jaarrond hoog. De larven van Culicoides impunctatus zijn semi-aquatische en verdrinken in open water, maar zijn ook kwetsbaar voor verdroging en mijden dus droge grond. In een geschikt habitat kunnen dichtheden van maximaal 700 individuen per $\mathrm{m}^{2}$ worden gevonden.

Culicoides impunctatus heeft in Schotland 2 generaties per jaar, met volwassen dieren vanaf begin mei tot eind september. Eitjes worden in batches van 30-100 na ongeveer 5 dagen na bevruchting afgezet. De larven komen binnen een dag uit en graven zich in de toplaag van de bodem. De larven zijn tegelijk omnivoor en detritivoor (eten van organisch materiaal in de bodem) en voeden zich met onder andere knuttenlarven, Protozoa, nematoden en groenalgen. Bij een temperatuurstijging en een kritisch aantal uren daglicht verpoppen de larven zich. Het popstadium duurt 1-2 dagen. Na de verpopping verschijnt het volwassen dier dat circa 20-30 dagen leeft. De larven van de tweede generatie overleven in het vierde stadium de winter. De larven ontwikkelen langzaam in vergelijking met andere soorten van dit geslacht. Dit is mogelijk een gevolg van het leven in een voedselarme bodem. De vrouwtjes kunnen zonder bloedmaal de eerste leg eitjes afzetten. De volwassen vrouwtjes dragen echter veel meer eitjes dan het aantal van de eerste leg. Voor de rijping van deze eitjes heeft ze een bloedmaal nodig. De soort bijt zoogdieren, zoals runderen, herten, schapen, mensen, katten, honden, muizen en konijnen. Er is geen specifieke voorkeur voor de mens als prooi. De vrouwtjes worden aangetrokken door donker gekleurde bewegende objecten, in het bijzonder in combinatie met de uitstoot van koolstofdioxide $\left(\mathrm{CO}_{2}\right)$. Een knut steekt niet maar bijt. Ze maakt een ondiepe wond en voedt zich met capillair bloed uit de wond. Na ongeveer 5 minuten is de knut volgezogen. Zodra het vrouwtje zich heeft gevoed scheidt ze een feromoon af die andere vrouwtjes aantrekt. De soort houdt zich laag bij de grond op of hoger in struiken of bos, in een vochtig(er) microklimaat. Van de soort is vooral veel overlast bekend in Schotland.

Culicoides festivipennis gr. heeft een voorkeur voor poelen met veel emergente planten (o.a. lisdodde (Typha), russen (Juncus), zegges (Carex)) in de oevers en verlandingszones, maar kan ook voorkomen in bijna alle natte organische milieus, drassige organische gronden, weinig begroeide, slibrijke bospoelen en dergelijke. De soort heeft 4-5 generaties per jaar en bijt vogels.

Culicoides punctatus leeft in natte graslanden waar vee weidt en mest aanwezig is en leeft ook tussen emergente vegetaties (o.a. lisdodde (Typha), russen (Juncus), zegges (Carex)) in de oevers van poelen, in organische moerassen en vochtige. De soort bijt vogels en zoogdieren.

Culicoides obsoletus is een bewoner van vochtige bladbodems in bos en boomholten (Kremer 1965), oeverzones van stilstaande wateren en moerassen, boomholtes, moerassen, rottende vegetatie, mengsels van mest en stro, organisch verrijkte bodems vooral nabij stallen en organisch verrijkte bodems op beschaduwde plaatsen, Sphagnum en veenbodems en met mest doorwerkte gronden, bijvoorbeeld kippenmest of paardenmest. De soort is ook gevonden in mineraliserende bodem met een hoge C:N ratio. Het was de meest dominante soort (99\%) in verse en oude mest en organisch verrijkte bodem, en komt overal voor waar organisch materiaal door de bodem is gemengd, bijvoorbeeld door menging met rottende maisplanten, oude koemest, rottend hooi en dergelijke. Rondom stallen en mesthopen is de soort algemeen. De soort lijkt waterverzadigde bodems en overstromingszones te mijden (. De larven kunnen niet drijven en verdrinken bij overspoeling. De optimale habitat lijkt een agrarisch bewerkte bodem met een stabiele vochtigheid (onverzadigde bodem), een hoge biologisch (decompositie) activiteit door wormen en mijten, $45 \%$ organisch materiaal, een $\mathrm{pH}$ 8.5-8.7 en het EGV 2.6-9.6 uS/cm in de omgeving van boerderijen.

Culicoides kibunensis is een soort van modderige bosgrond en weinig begroeide, slibrijke bospoelen. De soort bijt vogels.

Culicoides pictipennis ontwikkelt zich nabij boerderijen en in de oeverzones van poelen, vooral drinkpoelen. Het is een typische voorjaarssoort. De soort bijt vooral vogels. 
Culicoides pallidicornis is een algemene, wijdverspreide soort die zich vooral ontwikkelt in rottend blad onder houtige begroeiingen. De soort bijt zoogdieren. 